\title{
The first comprehensive data on the distribution of reptiles within the Southern Bug eco-corridor, Ukraine
}

\author{
Oleksandra Oskyrko ${ }^{1,2}$, Daniel Jablonski ${ }^{3}$ \\ 1 NGO «Ukrainian Nature Conservation Group» (UNCG), Gogol 40, 08600, Vasylkiv, Kyiv region, Ukraine \\ 2 Department of Zoology, Faculty of Science, Charles University, Viničná 7, 12844, Prague, Czech Republic \\ 3 Department of Zoology, Comenius University in Bratislava, Mlynská dolina, Ilkovičova 6, 84215 Bratislava, Slovakia \\ http://zoobank.org/06224CAD-47EC-45DF-BFD4-B50B46DA92F8 \\ Corresponding author: Oleksandra Oskyrko (sashaoskirko@gmail.com)
}

Academic editor: Yurii Kornilev • Received 25 December 2020 • Accepted 7 April 2021 • Published 26 April 2021

\begin{abstract}
This study provides distribution data for 12 species of reptiles in the Southern Bug eco-corridor located within the steppe zone, Mykolaiv Oblast (province), Ukraine. We compiled 935 records from published literature (324), from public databases (68), and from 12 field surveys we made in 2016-2020 (543). All records were mapped on to a grid of 10×10 km, representing the 294 cells of the studied area. We present new distributional data for Podarcis tauricus. For all the other species, our records add new localities that fall within areas where these reptiles were previously reported. Species richness and Shannon's H' index show that herpetofauna diversity was higher in the areas along the Southern Bug River. The maximum number of records within a single cell was 118 (for 10 species) in this oblast. Also the high number of identified reptile chorotypes (nine) within the Mykolaiv Oblast revealed that southern Ukraine is an important zoogeographical territory in Europe. These data provide the basis for future biogeographical and ecological studies and conservation priorities.
\end{abstract}

\section{Key Words}

Europe, mapping, Mykolaiv Oblast, occurrence, Reptilia, zoogeography

\section{Introduction}

Reliable maps that depict the historical and current distribution of species are an important component in conservation-related research (Sillero et al. 2014). As many reptile species' populations are declining on a global level (Wake and Vredenburg 2008; Sinervo et al. 2010; Böhme et al. 2013), their conservation is a research priority (Jetz et al. 2011; Sillero et al. 2014). Ukraine, especially in the southern lowland parts, is one of the least studied countries in Europe in terms of the distribution of amphibians and reptiles. A total of 26 species were recorded within Ukraine (including the Crimean Peninsula). Out of these, 21 species are native (Kurylenko and Verves 1999) and at least five are introduced or invasive (Darevsky and Szczerbak 1968; Darevsky 2006; Duz et al. 2012; Matvyeyev et al. 2013; Kurtyak and Kurtyak 2013; Krasylenko and Kukushkin 2017). Most of the herpetological research in Ukraine dates back to the Soviet Era (Yablokov 1976; Tarashchuk 1959; Bannikov et al. 1971). The country has less species distribution data compared to similar European areas (Sillero et al. 2014), which is typical of countries of the former USSR (see Zizka et al. 2020). The lowest diversity of reptile species has previously been observed in the zone of mixed and broad-leaved forests, and the greatest - in the steppe and forest-steppe (Tarashchuk 1959).

The Southern Bug River eco-corridor of the steppe zone is located in the south of Ukraine, Mykolaiv Oblast (Province) and encompasses an area of approx. 14,778 $\mathrm{km}^{2}$ (Fig. 1). This oblast is situated between the Republic of Moldova, and the Danube Delta and the Dnipro 


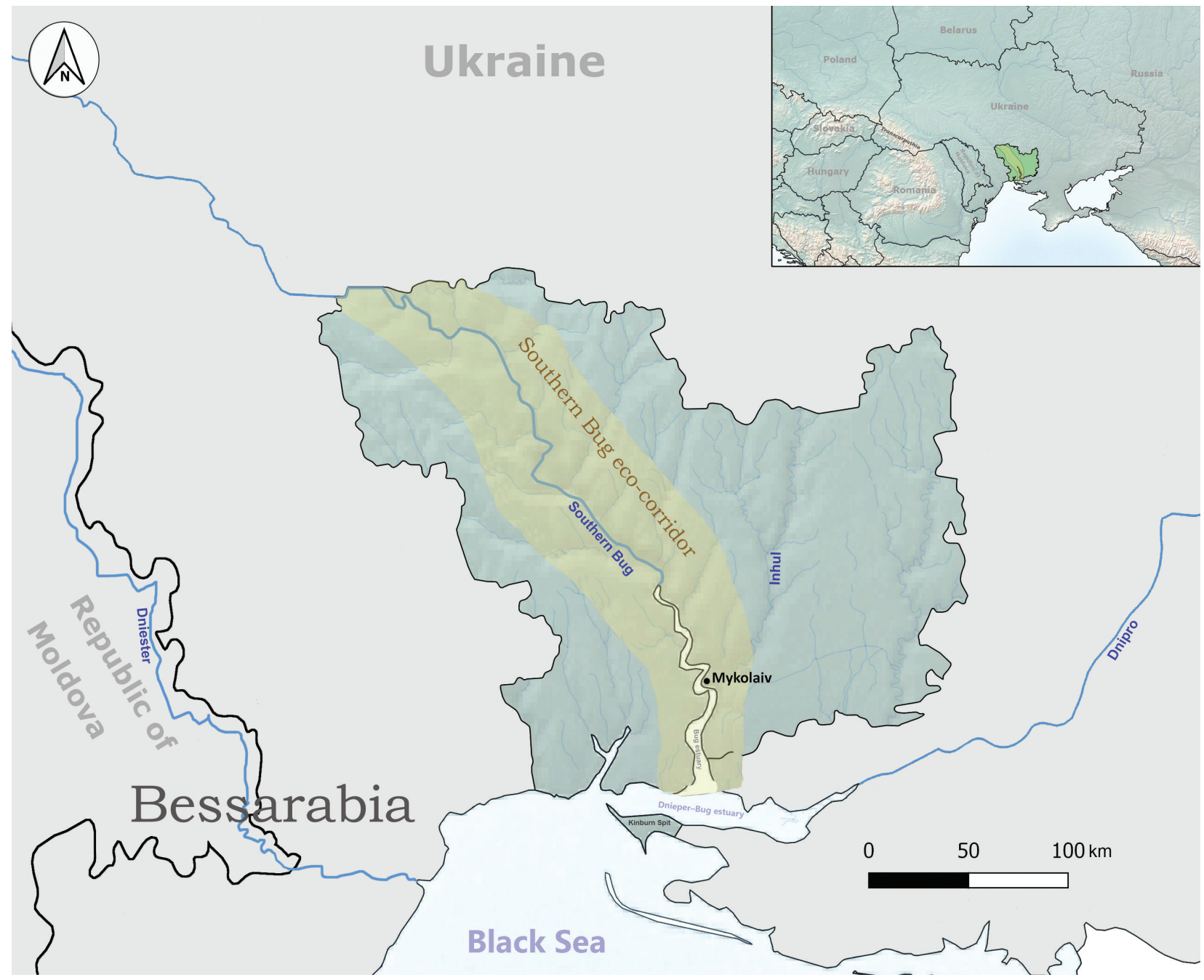

Figure 1. The study area (Mykolaiv Oblast, Ukraine) indicating geographic areas and places mentioned in the text. Yellow-tan marks the Southern Bug eco-corridor in the steppe zone.

and Dniester Rivers (which are significant biogeographic barriers) and contains the connecting habitat between the eastern Carpathian (Wallachian Plain) and the European steppe areas (Great European Plain; Kostyushin et al. 2007). Herpetologically, it is one of the least known territories in Europe (Kotenko 2006; Sillero et al. 2014). There are numerous conservation areas in the oblast but the most relevant protected area is the Buzk's Gard National Nature Park. In this national park the most ancient geological form in Ukraine (the Ukrainian crystalline shield) comes to the surface (rocky outcrops, slopes, floodplains). These unique ecosystems include rare, endemic and relict species of plants and animals (Didukh 2009; Akimov 2009; Kuzemko et al. 2020).

The Southern Bug River is also valuable for local herpetofauna species, most of which are protected at a national or international level (Akimov 2009; IUCN 2020). Based on published data, 12 species of reptiles are known from the Mykolaiv Oblast and most of them are distributed within the Southern Bug eco-corridor (Tarashchuk 2007). Although the Southern Bug is the only large river in Ukraine whose course is completely within the country, data on the reptile distribution along the river is very limited (Szczerbak 1993; Kurylenko and Verves 1999; Tarashchuk 2007). In this paper, we report on the first comprehensive study on the distribution of reptiles in this area.

\section{Material and methods}

The Southern Bug eco-corridor in the steppe zone begins from the northern part of the Mykolaiv Oblast to the Black Sea. The eco-corridor includes the valley of the Southern Bug River and land areas on both sides of the river (Fig. 1). We compiled a set of location data and created distribution maps for species based on three sources: (1) our own data; (2) published data (Yablokov 1976; Tsvelyh 1981; Szczerbak 1993; Kotenko 2000; Dotsenko and Radchenko 2005; Bilyakov and Tarashchyuk 2008; Dovzhenko 2013; Nekrasova 2013; Sillero et al. 2014; Marushchak et al. 2018; Redinov 2018; Suriadna et al. 2018; Mykytynets et al. 2019; Nekrasova et al. 2019; Voblenko et al. 2019); and (3) public databases (UkrBIN, 
http://www.ukrbin.com/; GBIF, http://www.gbif.org; iNaturalist, http://www.inaturalist.org). From the public databases we used only records with photos that allowed species identification. We identified species based on Arnold and Ovenden (2002) and followed the taxonomy of Speybroeck et al. (2020).

We obtained data from our own fieldwork performed in the years 2016-2020 (12 expeditions from 3 to 7 days) from April to September throughout the Southern Bug eco-corridor in the steppe zone and some other territories in the Mykolaiv Oblast. Field work was conducted throughout the day (8-10 hours of active field work) whenever weather conditions were seemingly optimal for surveying as many species as possible. Field surveys were primarily based on different selected transects of various lengths or by targeted species searches, covering all types of habitats. Most transects were only visited once. We employed the line transect method, recorded and identified all reptiles found roughly $5 \mathrm{~m}$ on both sides of the pathway (Lovich et al. 2012; McDiarmid et al. 2012). We collected data with dipnetting, netting, trawling of water bodies, stone-flipping and other refugia searches, and visual searching. Observations were documented with digital photographs of individuals when possible and surrounding habitats. Captured animals were released at the capture site. Also, we surveyed animals killed by people or vehicular traffic. We recorded coordinates and altitude for all observations using hand-held GPS units.

Published data with unspecified coordinates that could not be georeferenced to an actual locality were not included in this research. Occurrences without geographic coordinates were manually georeferenced to the finest scale possible using the information provided by the source and Google Earth (https://earth.google.com/). The accuracy of published localities was within $5 \mathrm{~km}$, except the data from Sillero et al. (2014) which was within 10-50 km. Although we focus on the Southern Bug eco-corridor in the steppe zone of Ukraine, we also included reptile records from all over Mykolaiv Oblast (own and published data).

We created all maps using QGIS Desktop 3.10.8 software (2019) (using the coordinate system UTM, zone $36 \mathrm{~N})$. Two types of maps were created: with precise GPS locations of the records and with the general distribution of species on the grid. We used a Universal Transverse Mercator (UTM) grid of $10 \times 10 \mathrm{~km}$ size. The grid for the whole Mykolaiv Oblast comprises 294 cells. We used original and literature data (only if exact coordinates were available) for altitude analysis. For literature data, the altitude was estimated using Google Earth. Chorotypes were identified according to the classification of Vigna Taglianti et al. (1999) with some adjustments (Table 1). To assess the diversity of reptiles in the Mykolaiv Oblast, we calculated species richness, namely Shannon's diversity index $\left(H^{\prime}\right)$. Species richness refers to the total number of species recorded per grid cell. Shannon's index was calculated in R 4.0.2 (R Core Team 2020) using the "vegan" package (Oksanen et al. 2019).

\section{Results and discussion}

\section{Species records}

The compiled checklist of reptile species occurring in Mykolaiv Oblast includes 12 species of four families, and it is based on 935 records (543 original data, 324 published, 68 from public databases; Table 1). The list of recorded species with names of localities and UTM codes is presented in the Suppl. material 1. The original distribution data (coordinates) are available on request. Merging multiple observations of the same species within the same grid cell resulted in 282 species-cell observations remaining. Some species frequently represented by numerous records per grid cell showed higher values in the percentage of observations in comparison to the percentage of occupied grid cells (e.g. Lacerta viridis; Table 1), or vice versa, occupied more grid cells than the general overall trend would predict, judging by their number of observations (e.g. Emys orbicularis; Table 1). This is likely to be due to both habitat specificity as well as relative ease of observation; other types of biased sampling (seasonal and behavioural effects) may add to this imbalance.

The western and eastern parts of the Mykolaiv Oblast have visible gaps in the mapping (Fig. 2). Most data

Table 1. Reptiles with chorotype classification of the Mykolaiv Oblast, Ukraine. Overview of available records per species, including number of records $(\mathrm{Rn})$, percent of records from total dataset $(\mathrm{R} \% ; \mathrm{n}=935)$, number of occupied grid cells $(\mathrm{Cn} ; 10 \times 10 \mathrm{~km})$ and percent of occupied grid cells from total number of grid cells $(\mathrm{C} \% ; \mathrm{n}=294)$.

\begin{tabular}{|c|c|c|c|c|c|}
\hline Species & $\mathbf{R n}$ & $\mathbf{R} \%$ & Cn & $\mathrm{C} \%$ & Chorotype \\
\hline Emys orbicularis & 95 & 10.3 & 41 & 13.8 & Turano-European-Mediterranean \\
\hline Eremias arguta & 26 & 2.7 & 16 & 5.4 & Turano-European \\
\hline Lacerta agilis & 50 & 5.2 & 29 & 9.8 & Euro-Siberian \\
\hline Lacerta viridis & 323 & 34.6 & 32 & 10.8 & Southern-European \\
\hline Podarcis tauricus & 26 & 2.6 & 9 & 3 & Eastern-Mediterranean \\
\hline Natrix natrix & 39 & 4.2 & 24 & 8.1 & Central Asiatic- European-Mediterranean \\
\hline Natrix tessellata & 55 & 6 & 32 & 10.8 & Turano-European \\
\hline Coronella austriaca & 7 & 0.7 & 7 & 2.3 & European \\
\hline Dolichophis caspius & 171 & 18.2 & 54 & 18.3 & Eastern-Mediterranean \\
\hline Elaphe sauromates & 34 & 3.6 & 23 & 7.8 & Turano-Mediterranean \\
\hline Zamenis longissimus & 23 & 2.3 & 7 & 2.3 & Southern-European \\
\hline Vipera renardi & 86 & 9.3 & 8 & 2.7 & Central Asiatic-European \\
\hline Total & 935 & 99.9 & 282 & 95.1 & 9 \\
\hline
\end{tabular}


A

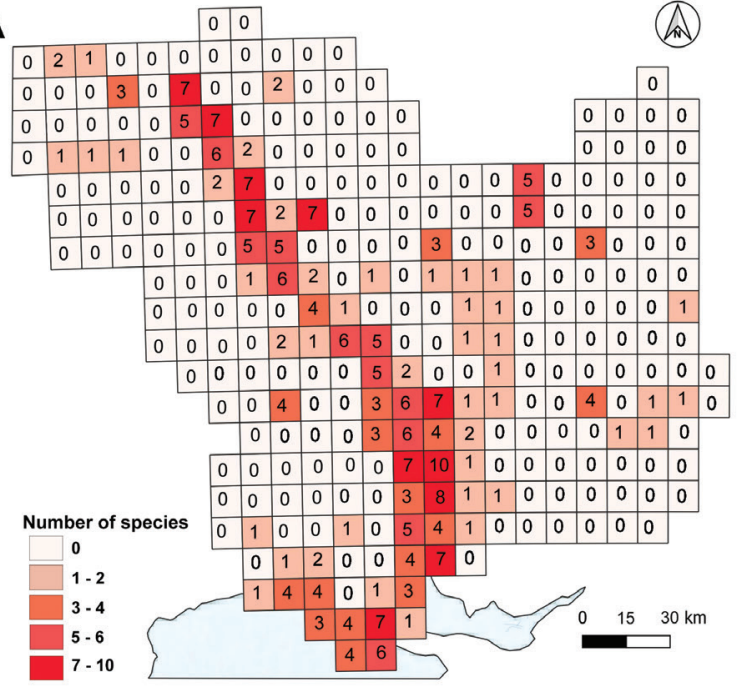

B

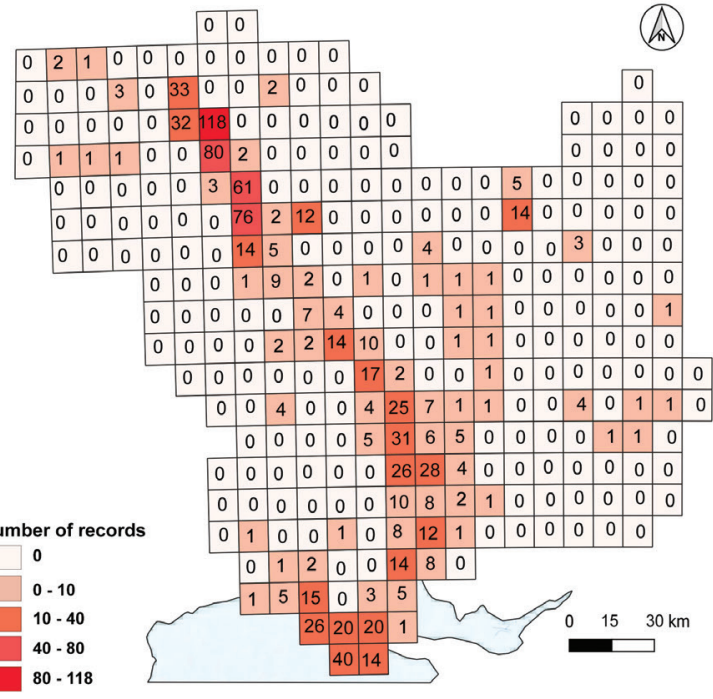

C

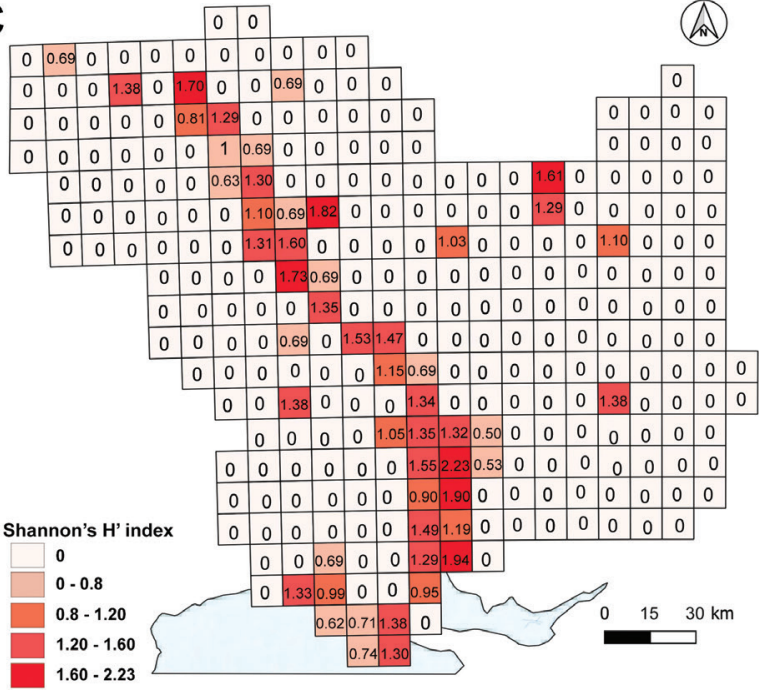

Figure 2. Number of herpetofaunal species (A), number of records (B) and Shannon's diversity index $(\mathbf{C})$ within a $10 \mathrm{~km}$ grid of the Mykolaiv Oblast. are concentrated along the Southern Bug River which served as the working base for most of the field trips. The frequency distribution of specific grid occupancy rates (number of grid cells by number of herpetological species and records) was higher in the north-central part of the oblast and around the city of Mykolaiv (Fig. 2). The highest number of species within a single cell was ten and the maximum number of records was 118 (for seven species) in the northern part of the oblast. The largest number of species and records were both within the Southern Bug eco-corridor, also reflected by the Shannon's H' index (Fig. 2).

The Mykolaiv Oblast is a lowland area that gradually decreases from the north to the south in the Black Sea region. The elevations within the landscape range from -3 to $255 \mathrm{~m}$ a.s.l. The observed herpetofauna occurred from -2 to $126 \mathrm{~m}$ a. s. 1. (Fig. 3). Lacerta viridis was the species with the highest recorded elevation with the majority of records at 0-98 m a.s.l. Elaphe sauromates and Dolichophis caspius had the lowest elevation (-2 $\mathrm{m}$ ) that were found on the Kinburn Spit (the lowest area in the oblast).

Our analysis distinguished nine chorotypes of reptiles in the studied area: Turano-Europeo-Mediterranean, Centralasiatic-European, Euro-Siberian, SouthernEuropean, Eastern-Mediterranean, CentralasiaticEuropeo-Mediterranean, Turano-European, European, Turano-Mediterranean (sensu Vigna Taglianti et al. 1999; Table 1). Lacerta viridis and Zamenis longissimus belong to the Southern-European chorotype. Podarcis tauricus and D. caspius - the Eastern-Mediterranean chorotype, and Eremias arguta and Natrix tessellata are the Turano-European representatives. The remaining chorotypes are represented by a single species. We include further details on our observations and comment on the relevant literature in the following species accounts.

\section{Emydidae}

\section{Emys orbicularis Linnaeus, 1758}

Numbers of records. 95 (10.3\% of the data).

Number of grid cells. 41 (13.8\% of the entire grid; Table 1; Figs 4, 8A).

Comments. Widely distributed in the steppe zone of Ukraine, most abundant in the deltas of big rivers (Kotenko 2000). Most records are concentrated along the Southern Bug River valley. Known from the territory of the Buzk's Gard National Nature Park (near Migia, Yuzhnoukrainsk), Kinburn Spit and near the city of Mykolaiv (Kotenko 2000; Dotsenko and Radchenko 2005; Sillero et al. 2014). Isolated observations from different parts of the Mykolaiv Oblast (Kotenko 2000; Dotsenko and Radchenko 2005). Although all our records represent new localities, they fall within the areas where these turtles were previously known. 


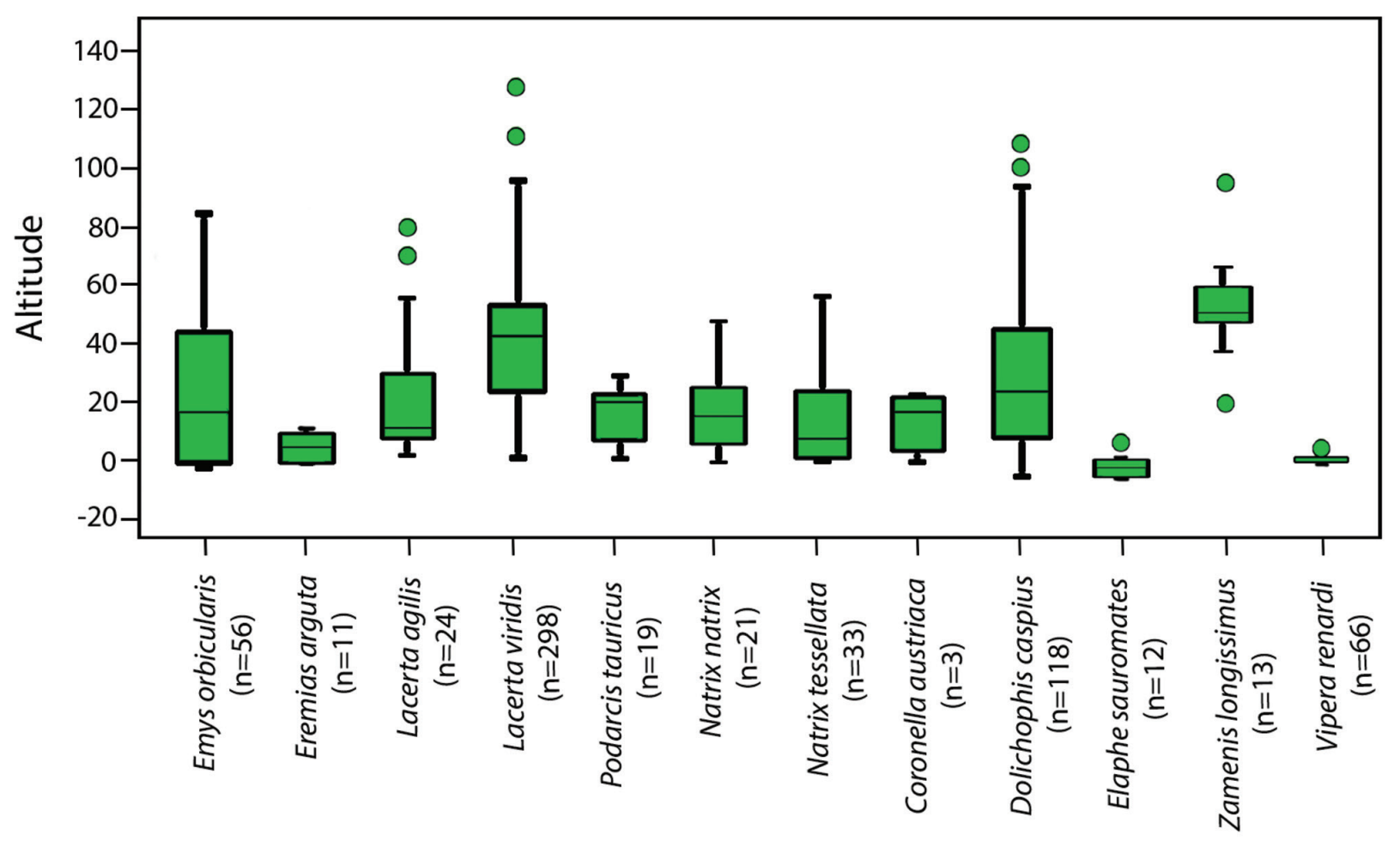

Figure 3. Altitudinal distribution of the reptile species in the Mykolaiv Oblast, Ukraine.

\section{Lacertidae}

\section{Eremias arguta (Pallas, 1773)}

Numbers of records. 26 (2.7\% of the data).

Number of grid cells. 16 (5.4\% of the entire grid; Table 1; Figs 4, 8B)

Comments. Eremias arguta was reported from the northern part and along the Southern Bug River to the Black Sea coast (Szczerbak 1993; Dotsenko and Radchenko 2005; Tarashchuk 2007; Sillero et al. 2014). We found this species only in four localities: one north of Mykolaiv city near the Balovne Village, and three near the estuary Galitsynove Village and Kinburn Spit. Historic records from the northern part of the Mykolaiv Oblast are particularly interesting because this species has practically disappeared from central Ukraine. We checked these points (Oniscoves, Sirovo, Rybakivka, Oleksandrivka and Voznesensk villages; Szczerbak 1993; Dotsenko and Radchenko 2005), but did not find the species there. In Ukraine, the species' range is limited to the steppe and, partially, the forest-steppe zones. It inhabits biotopes with sandy and sandy-shells soils with thin psammophilous steppe and halophilous herbaceous vegetation (Szczerbak 1993). As forests grow and the crowns of the trees close, E. arguta gradually disappears. An increase of the projective cover of herbaceous vegetation leads to the same result (Polynova and Mishustin 2020). Strict requirements for substrate and light lead to a mosaic-strip character of the subspecies' distribution (Kotenko 1986). We hypothesize that we did not find the species in the north because previously suitable habitats have been planted with forests in the 1990s (Tkach 2012).

\section{Lacerta agilis Linnaeus, 1758}

Number of record. 50 ( $5.2 \%$ of the data).

Number of grid cells. $29(9.8 \%$ of the entire grid; Table 1; Figs 4, 8C).

Comments. This species is rare in southern Ukraine, although common in the rest of the country (Tarashchuk 1959; Yablokov et al. 1976). The Sand lizard has mosaic distribution in the Mykolaiv Oblast (Dotsenko and Radchenko 2005; Nekrasova 2013; Sillero et al. 2014), near the borders of the eco-corridor. Sightings are relatively uncommon and there are significant gaps in the distribution in parts of the oblast. Observations are mainly located in the centre of the oblast, which might be related to a relatively higher sampling effort in that area, as well as a locally higher availability of suitable habitat. Most of the individuals have been observed near fields, gardens or pastures.

\section{Lacerta viridis Laurenti, 1768}

Number of records. 323 ( $34.6 \%$ of the data).

Number of grid cells. $32(10.8 \%$ of the entire grid; Table 1; Figs 5, 8D, E).

Comments. This species showed higher values in the percentage of observations than the number of observa- 


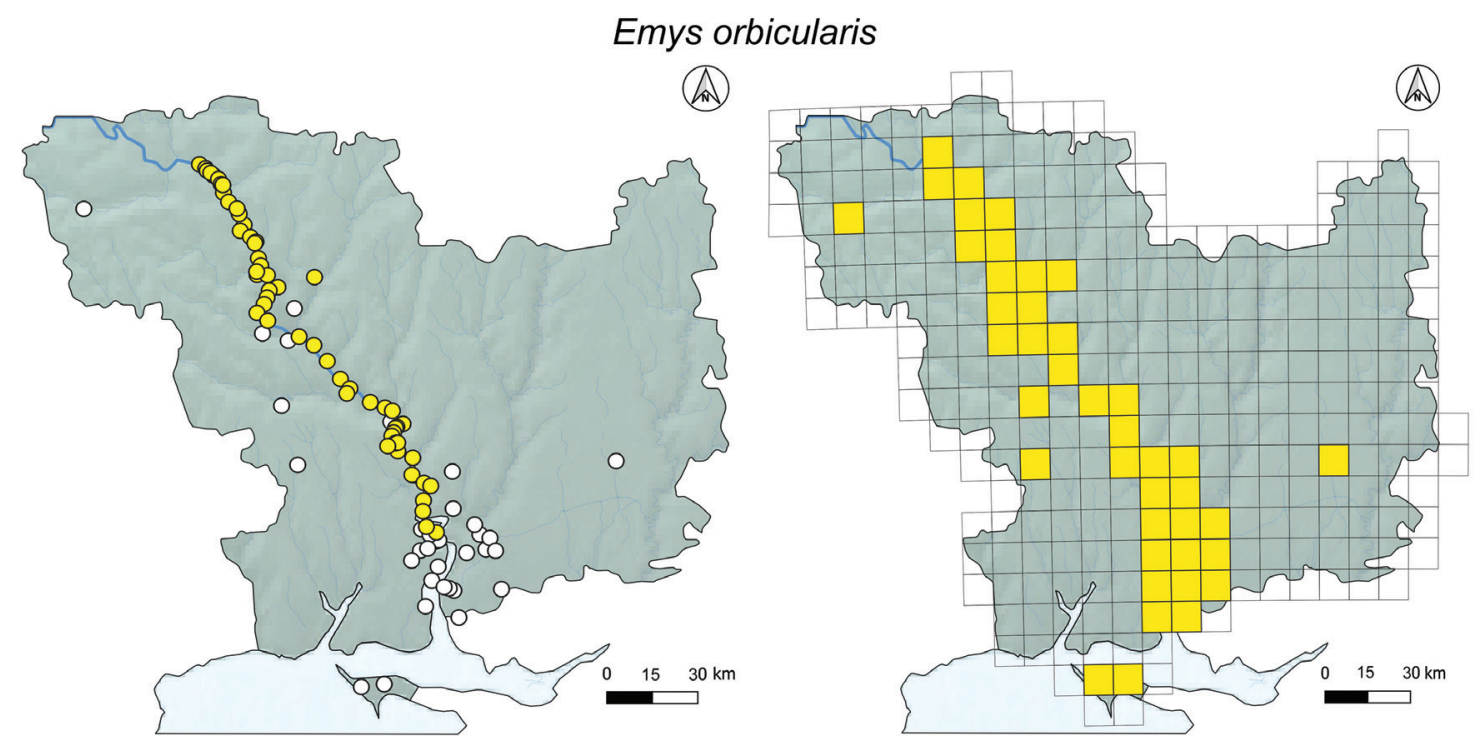

\section{Eremias arguta}

(ain)

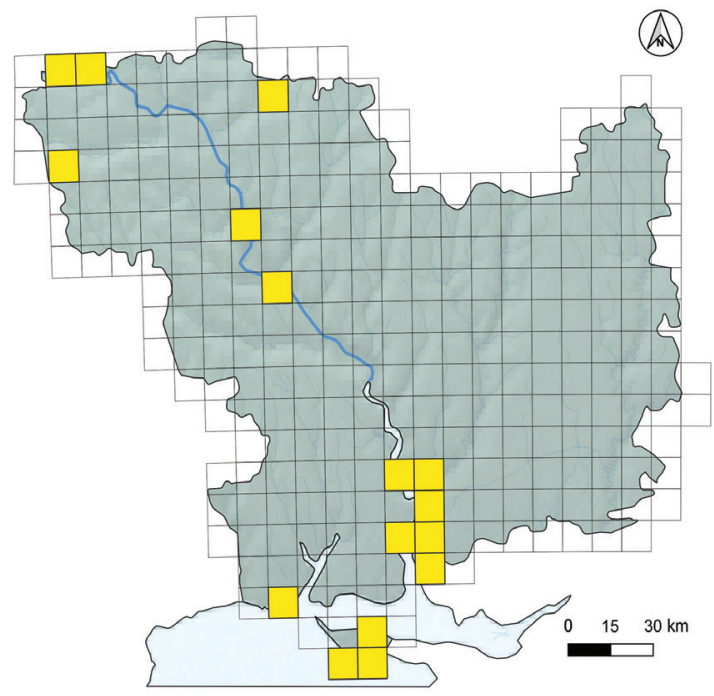

\section{Lacerta agilis}
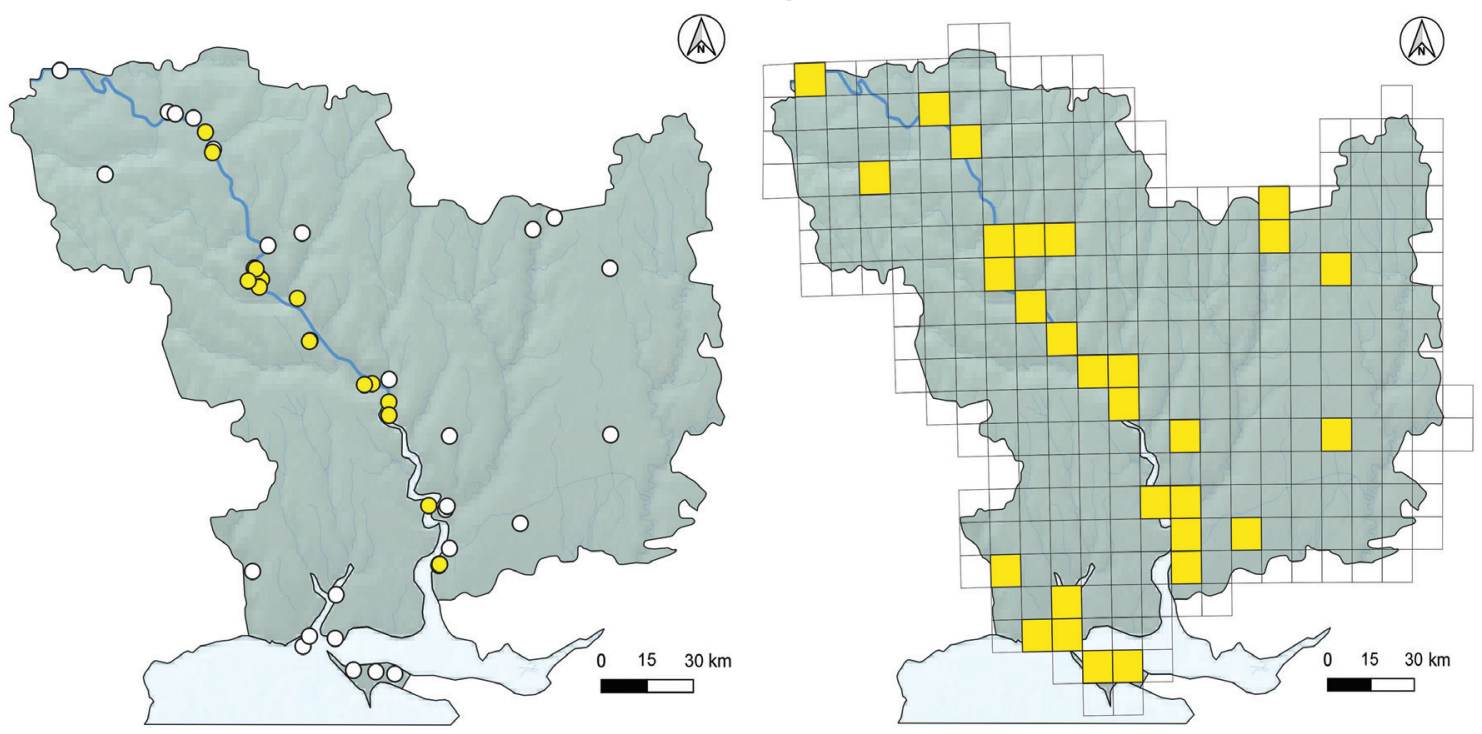

Figure 4. Distribution of (species) within the Mykolaiv Oblast (Ukraine), based on localities (left; white circles - literature and public database data, yellow circles - authors' data) and $10 \mathrm{~km}$ UTM grid (right; yellow squares - species recorded). 


\section{Lacerta viridis}
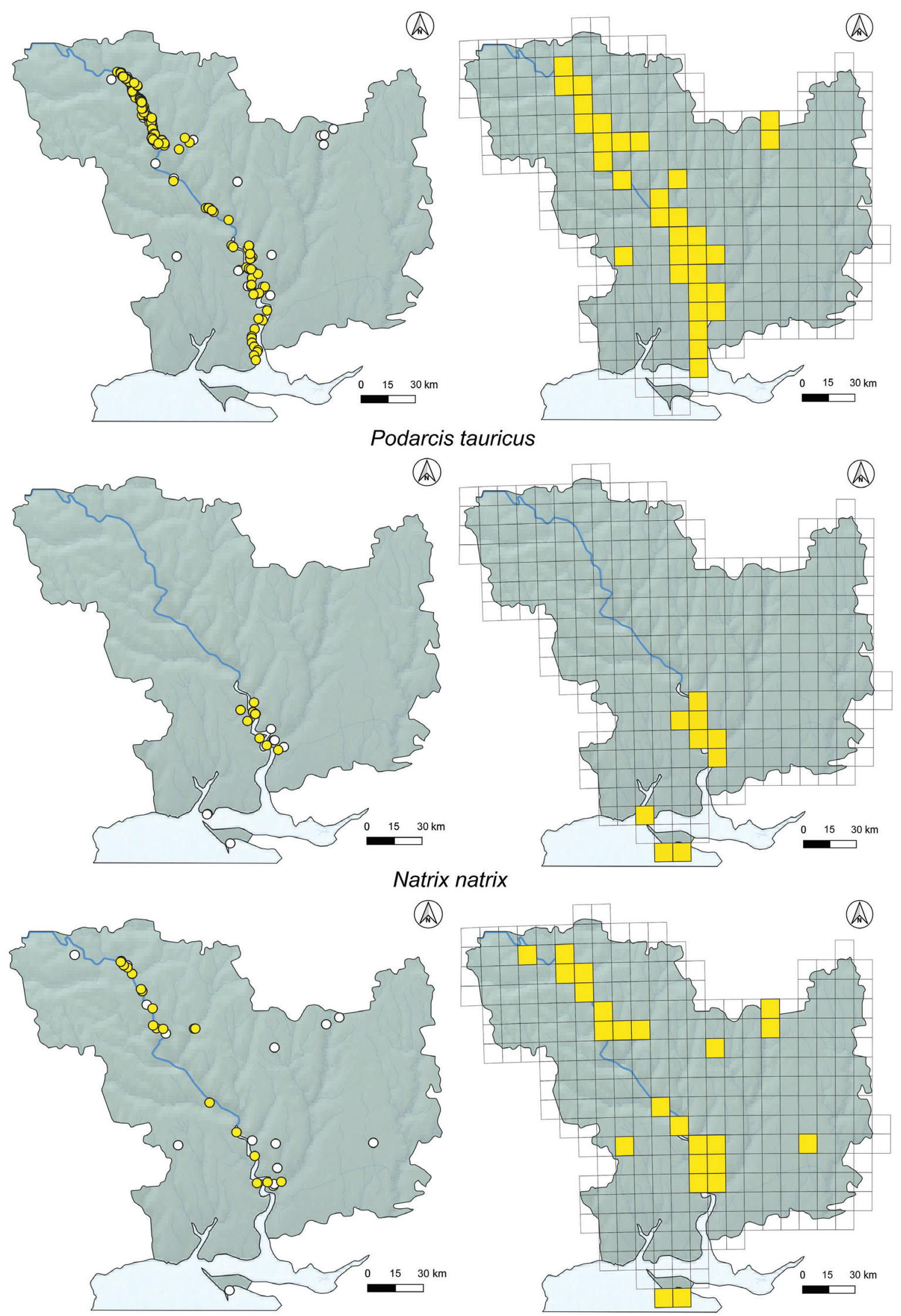

Figure 5. Distribution of (species) within the Mykolaiv Oblast (Ukraine), based on localities (left; white circles - literature and public database data, yellow circles - authors' data) and $10 \mathrm{~km}$ UTM grid (right; yellow squares - species recorded). 
tions per grid cell. It is known mainly from the Buzk's Gard National Nature Park and near Mykolaiv (Dotsenko and Radchenko 2005; Sillero et al. 2014; Suriadna et al. 2018; Mykytynets et al. 2019). Some records were made in the Inhul River valley (north-eastern part of the Mykolaiv Oblast; Dotsenko and Radchenko 2005; Nekrasova 2013). Most of our own records were along the valley of the Southern Bug River (from Pervomaisk to the estuary). The highest number of records were from Buzk's Gard National Nature Park (Fig. 10D). In contrast to the other lizards, we found this species often and in high numbers.

\section{Podarcis tauricus (Pallas, 1814)}

Number of records. 26 (2.6\% of the data).

Number of grid cells. Nine (3\% of the entire grid; Table 1; Figs 5, 8F).

New localities. Near the villages Sebine $\left(47.15^{\circ} \mathrm{N}\right.$, $\left.31.85^{\circ} \mathrm{E}\right)$, Novohryhorivka $\left(47.11^{\circ} \mathrm{N}, 31.76^{\circ} \mathrm{E}\right)$, Kamyana Balka $\left(47.06^{\circ} \mathrm{N}, 31.81^{\circ} \mathrm{E}\right)$ and Trihati $\left(47.10^{\circ} \mathrm{N}, 31.87^{\circ} \mathrm{E}\right.$; Fig. 10C)

Comments. Density of this species seems relatively low in this oblast (Dotsenko and Radchenko 2005). In Ukraine the northern border of the range of this species is south of the city of Mykolaiv (Böhme et al. 2009). The species was reported from near Ochakov, on the Kinburn Spit and within Mykolaiv (Dotsenko and Radchenko 2005; Dovzhenko 2013). Our observations were made $60-80 \mathrm{~km}$ north of the previous reports. Two records were from the left bank of the South Bug River, versus 16 from the right (Fig. 10C).

\section{Natricidae}

\section{Natrix natrix (Linnaeus, 1758)}

Number of records. 39 (4.2\% of the data).

Number of grid cells. 24 (8.1\% of the entire grid; Table 1; Figs 5, 9A).

Comments. This species is fairly frequently observed and distributed in different parts of the oblast (Dotsenko and Radchenko 2005; Nekrasova 2013; Sillero et al. 2014). We found most individuals in the Oleksandrivske Reservoir and in the floodplains near Mykolaiv. Its range is similar to that of $N$. tessellata and these species can occur sympatrically. The records of $N$. natrix were fewer than those of $N$. tessellata presumably because there are not a lot of suitable habitats for this species in this oblast.

\section{Natrix tessellata Laurenti, 1768}

Number of records. 55 ( $6 \%$ of the data).

Number of grid cells. $32(10.8 \%$ of the entire grid; Table 1; Figs 6, 9B).
Comments. This species is common in Mykolaiv (Kotenko et al. 2011), but has a scattered distribution, found mostly around the Southern Bug River valley (Dotsenko and Radchenko 2005; Nekrasova 2013; Sillero et al. 2014). We also observed this species along the entire valley of the Southern Bug River.

\section{Colubridae}

\section{Coronella austriaca Laurenti, 1768}

Number of records. Seven $(0.7 \%$ of the data).

Number of grid cells. Seven $(2.3 \%$ of the entire grid; Table 1; Figs 6, 9C).

Comments. This species is rare in the Mykolaiv Oblast. It was recently recorded from Kinburn Spit (Mykytynets et al. 2019). We confirmed the finding of an individual near Mykolaiv (Zaichevsk village) reported in iNaturalist (https://www.inaturalist.org/observations/14612688). We found the snake in a steppe area with small shrubs (Fig. 10A). The data of Sillero et al. (2014) (36TUT3 and 36TVS1) reflect historic records of populations that are likely no longer present. In 1979, this species was recorded on rocky banks of the Southern Bug River in the areas of the South Ukrainian Nuclear Power Plant (Tsvelyh 1981), but recent surveys (Kotenko et al. 2008, this study) have failed to detect it despite intensive investigation.

\section{Dolichophis caspius (Gmelin, 1789)}

Number of records. 171 ( $18 \%$ of the data).

Number of grid cells. 54 (18.3\% of the entire grid; Table 1; Figs 6, 9D).

Comments. This is the most common snake with a high number of observations per grid cell (Table 1). This species is known throughout the Mykolaiv Oblast (Dotsenko and Radchenko 2005; Tarashchuk 2007; Bilyakov and Tarashchyuk 2008; Nekrasova 2013; Sillero et al. 2014; Marushchak et al. 2018; Redinov 2018; Mykytynets et al. 2019; Nekrasova et al. 2019; Voblenko et al. 2019). We found multiple individuals within the Southern Bug eco-corridor in the steppe zone and a single one near the village of Snihurivka. Most records were from Buzk's Gard National Nature Park (Fig. 10D). The known distribution for this species shows a broad occurrence throughout the oblast, albeit with significant gaps, most likely due to lack of sampling. We found this species more often than other snakes in this oblast.

\section{Elaphe sauromates (Pallas, 1814)}

Number of records. 34 (3.6\% of the data).

Number of grid cells. 23 (7.8\% of the entire grid; Table 1; Figs 7, 9E). 
Comments. Records of this species are scattered; it is recorded infrequently and it is unclear to what extent this is due to its secretive habits, actual rareness or other factors. The species has mosaic distribution in the studied area and is often found in the Inhul River valley and in the eco-corridor near Mykolaiv (Tarashchuk 2007; Bilyakov and Tarashchyuk 2008; Sillero et al. 2014; Redinov 2018; Jablonski et al. 2019; Mykytynets et al. 2019; Voblenko et al. 2019). We have only two records of this species near the villages of Zaichevsk and Peresadivka.

\section{Zamenis longissimus (Laurenti, 1768)}

Number of records. 23 (2.3\% of the data).

Number of grid cells. Seven $(2.3 \%$ of the entire grid; Table 1; Figs 7, 9F).

Comments. In Ukraine, Z. longissimus reaches the eastern border of the European part of its range (Böhme 1993). Populations are concentrated mainly in the western part of the country; most individuals were recorded from Transcarpathia (Szczerbak and Szczerban' 1980; Darevsky and Orlov 1988). In the Middle Dniester region it is extremely rare or has completely disappeared (Dotsenko et al. 2013); there is also a stable population quite remote from the main part of the range in the valley of the Southern Bug River (Dotsenko and Radchenko 2005; Bilyakov and Tarashchyuk 2008; Dotsenko et al. 2013; Sillero et al. 2014; Suriadna et al. 2018; Voblenko et al. 2019). Records for the Mykolaiv Oblast seem distributed rather sparsely. Our records were from Mygiya to the village of Semenivka. Also, in September 2020, two adults were found near Yuzhnoukrainsk. The population is distributed in warm forested areas with hilly or rocky habitats with proper insolation and varied vegetation (Fig. 10B). A population was reported from the Trykratskyi Forest (UkrBIN ID \#113093).

\section{Viperidae}

\section{Vipera renardi (Christoph, 1861)}

Number of records. 86 (9.3\% of the data).

Number of grid cells. eight $(2.7 \%$ of the entire grid; Table 1; Fig. 7).

Comments. In 2016, we confirmed literature reports from Kinburn Spit (Dotsenko and Radchenko 2005; Kolomiets et al. 2008). In the following years, this species was repeatedly reported for this area (Mizsei et al. 2018; Redinov 2018; Mykytynets et al., 2019). Despite Sillero et al. (2014) reporting the species from the estuary of the Southern Bug River and Mykolaiv, the species' presence there remains questionable, due to the lack of recent records (see Baybuz et al. 2011; Mizsei et al. 2018).

\section{Species diversity and biogeography}

Our study presents results based on the most complete database of reptile occurrences in the Southern Bug eco-corridor to date, including data on all species currently known to occur in this oblast. Our findings corroborate the presence of most species reported in the past. Unfortunately, the Southern Bug eco-corridor in the steppe zone still lacks detailed and comprehensive data on the distribution of the local herpetofauna. Previous published studies were focused on the territory of the Buzk's Gard National Nature Park (Bilyakov and Tarashchyuk 2008; Suriadna et al. 2018; Nekrasova et al. 2019), Kinburn Spit (Redinov 2018; Voblenko et al. 2019), the vicinity of Mykolaiv (Dotsenko and Radchenko 2005; Dovzhenko 2013), or the data were presented without exact location (Tarashchuk 1959, 2007; Strugren and Rădulescu 1961; Kurylenko and Verves 1999; Kostyushin et al. 2007). Although we added valuable information, further surveys are needed.

The studied oblast is inhabited by reptiles that are locally abundant (e.g., L. viridis, D. caspius), or rare (e.g., C. austriaca, V. renardi). Undoubtedly, L. viridis and D. caspius in Ukraine have uneven distribution ranges, while $V$. renardi and especially $C$. austriaca are much more widespread; but probably with low densities and observed rarely. The most abundant species is L. viridis with the highest number of sightings, probably because it is an easily detectable species (Table 1). Still, this species is rare in Ukraine and the density of many of its populations is insufficiently studied (Kotenko and Sytnik 2009).

We added new locality data for $P$. tauricus that expands its known range (Fig. 5). This species is distributed almost all over Crimea (Kotenko and Kukushkin 2010), while in the south of the steppe zone of Ukraine, it is characterised by a mosaic distribution (most of the records are from the Odessa and Kherson regions; Dotsenko and Radchenko 2005; Kotenko 2007; Dovzhenko 2013). The northernmost populations of $P$. tauricus were so far recorded in the vicinity of Mykolaiv (Dovzhenko 2013). We, however, found new populations further north during our investigations.

The data for $C$. austriaca were outdated in the studied area but we confirmed that this species is present in Mykolaiv Oblast (Table 1; Figs 6, 9C). The rarity of records for C. austriaca might be a result of the species' low detectability and overall secretive lifestyle.

Given that the Mykolaiv Oblast is situated in the lowlands, the majority of the records of reptiles were from low elevations (see species list and Fig. 3). Our study reports the lower elevation limit for most of the observed species.

Our overall data, however, showed notably higher diversity in the Southern Bug eco-corridor (including numbers of species and records) compared to other areas in Mykolaiv Oblast (Fig. 2). This could be explained by higher habitat diversity (Kostyushin et al. 2007; Kuzemko et al. 2020). According to our results, diversity was higher in the northern part of the oblast which was seemingly less impacted by human activities and includes 


\section{Natrix tessellata}
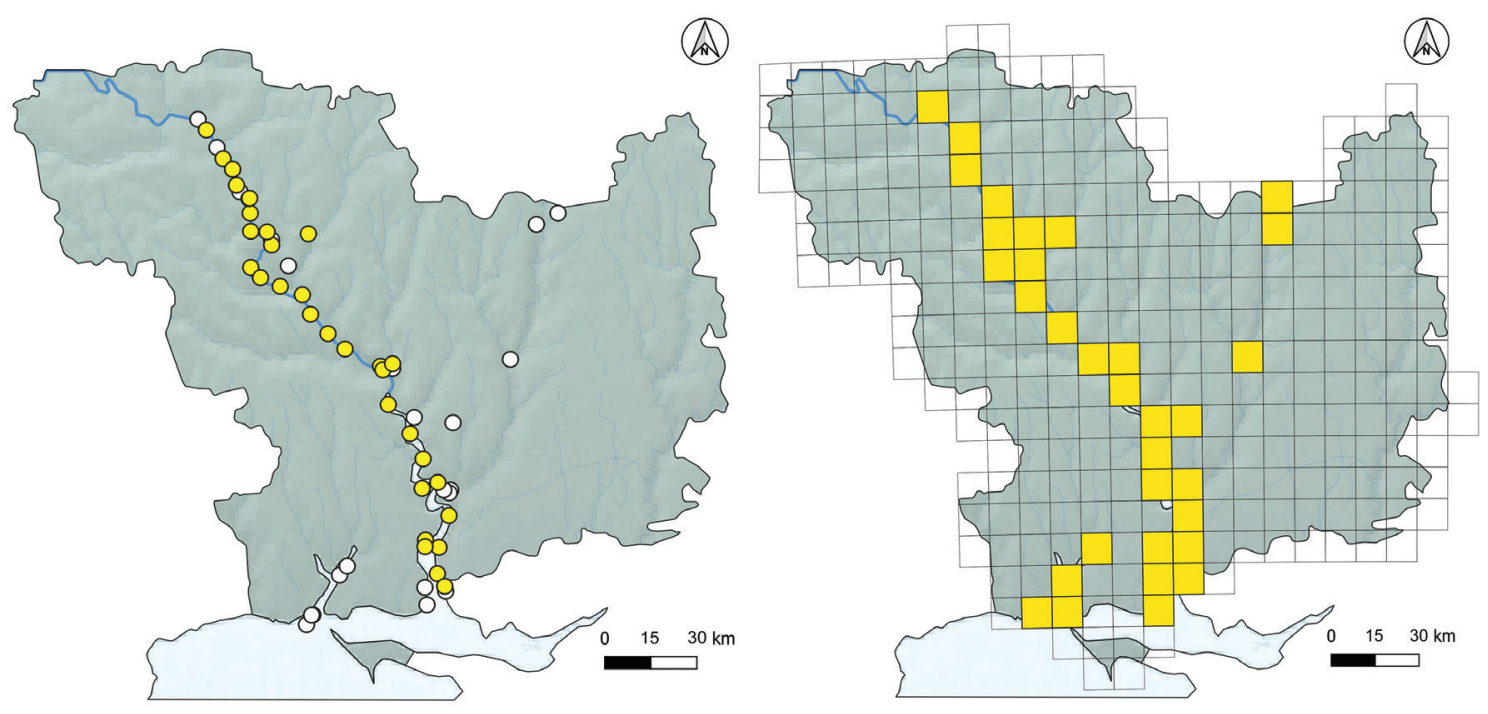

Coronella austriaca
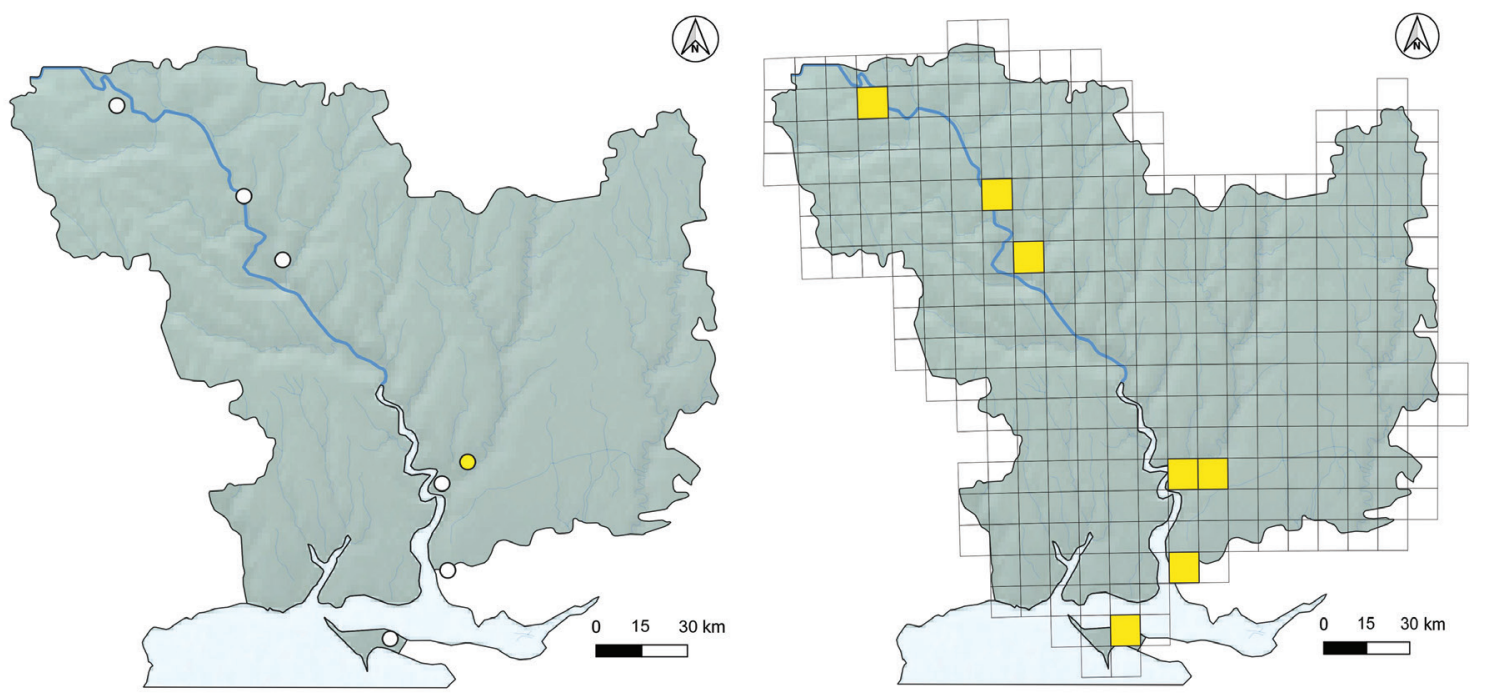

Dolichophis caspius
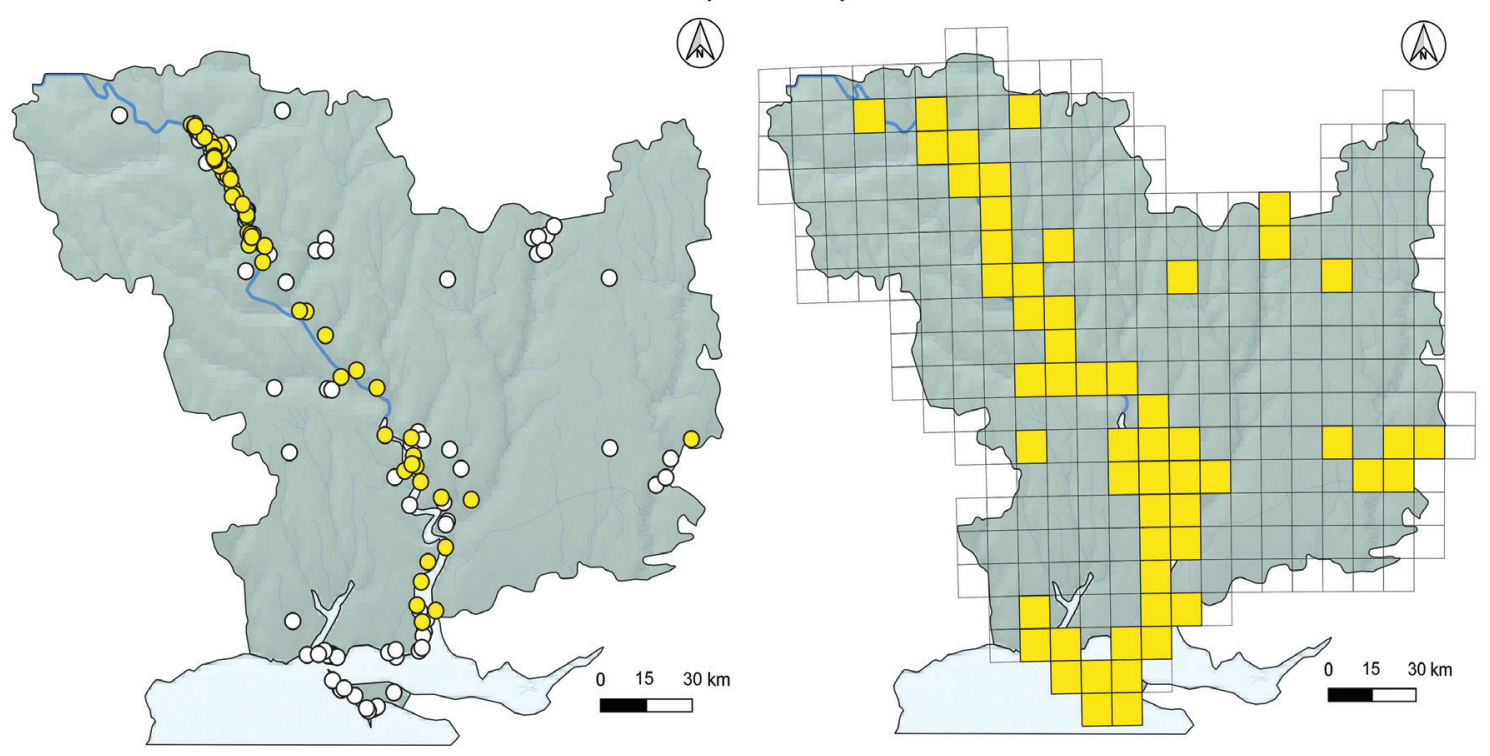

Figure 6. Distribution of (species) within the Mykolaiv Oblast (Ukraine), based on localities (left; white circles - literature and public database data, yellow circles - authors' data) and $10 \mathrm{~km}$ UTM grid (right; yellow squares - species recorded). 


\section{Elaphe sauromates}

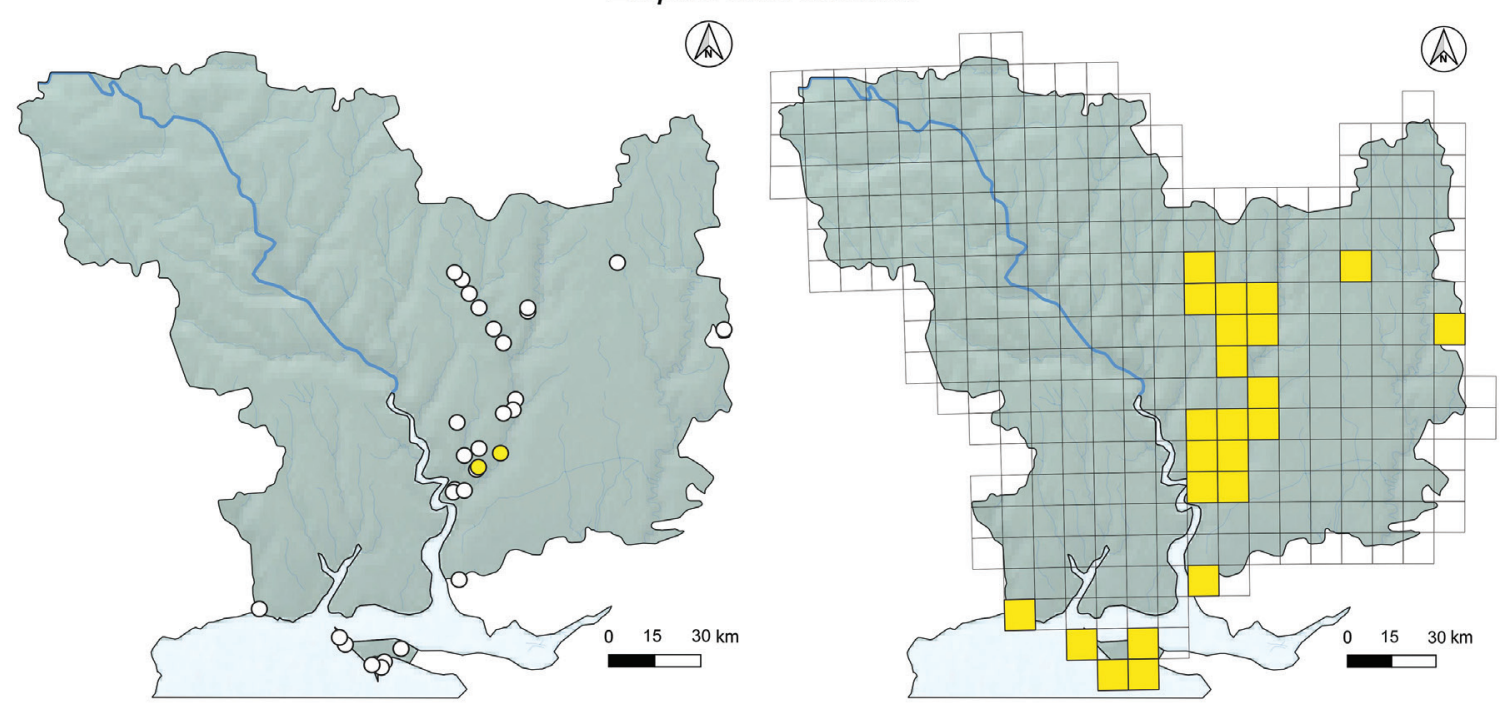

\section{Zamenis longissimus}
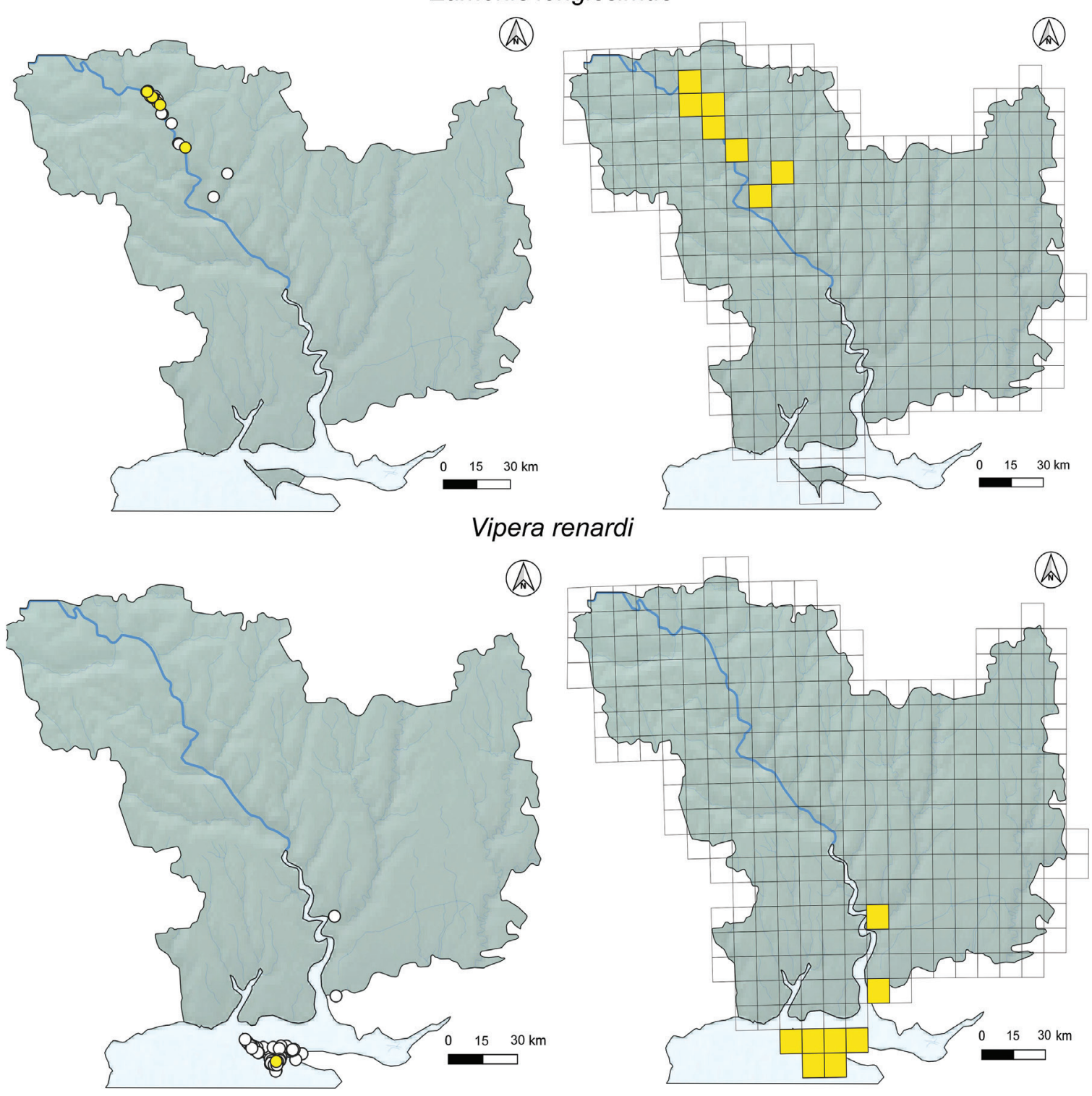

Figure 7. Distribution of (species) within the Mykolaiv Oblast (Ukraine), based on localities (left; white circles - literature and public database data, yellow circles - authors' data) and $10 \mathrm{~km}$ UTM grid (right; yellow squares - species recorded). 

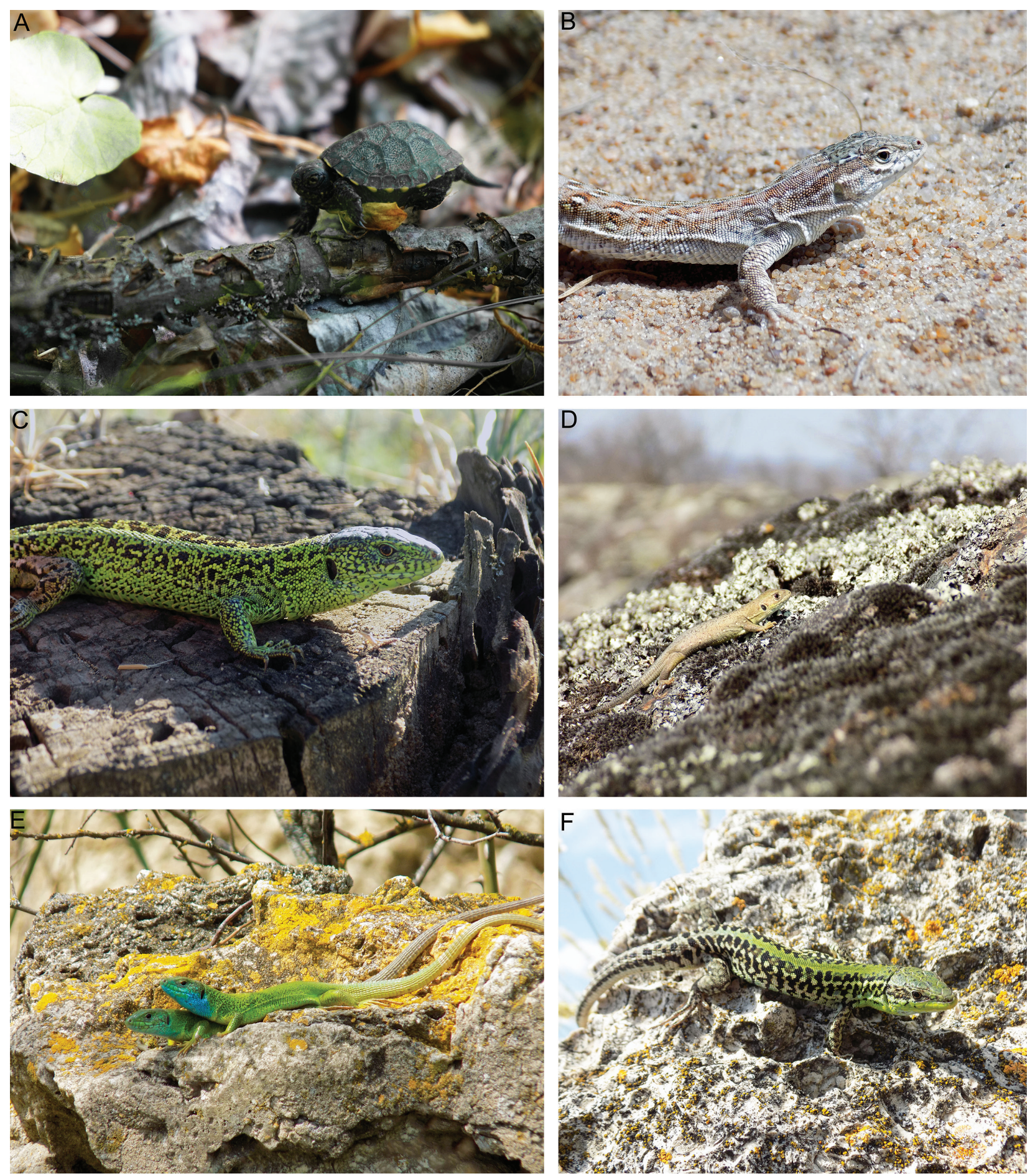

Figure 8. Representative pictures of species of herpetofauna: A. Emys orbicularis, juvenile, Hrushivka; B. Eremias arguta, Balovne; C. Lacerta agilis, Voznesensk; D. Lacerta viridis, juvenile, Kuripchyne; E. Lacerta viridis, male (front) and female, Voznesensk; F. Podarcis tauricus, Novohryhorivka. Photographs by D. Shyriaieva (A), O. Oskyrko (B, C, D, E, F).

some protected areas (Fig. 2). On the other hand, in the south, the species diversity was higher in the vicinity of Mykolaiv city than in the northern part and other territories in Mykolaiv Oblast. This can mean synanthropy for many species. The species richness and Shannon's H' index follow a similar pattern, with most species concentrated along the Southern Bug eco-corridor. This can be because most of this area is part of the Buzk's Gard Na- tional Nature Park which experiences low anthropogenic impact. This implies that the Southern Bug eco-corridor is a territory of interest for future reptile conservation activities in Ukraine.

The high number of identified reptile chorotypes within the Mykolaiv Oblast indicates that Ukraine is an important territory from a zoogeographical point of view (Table 1). A detailed zoogeographic classification 

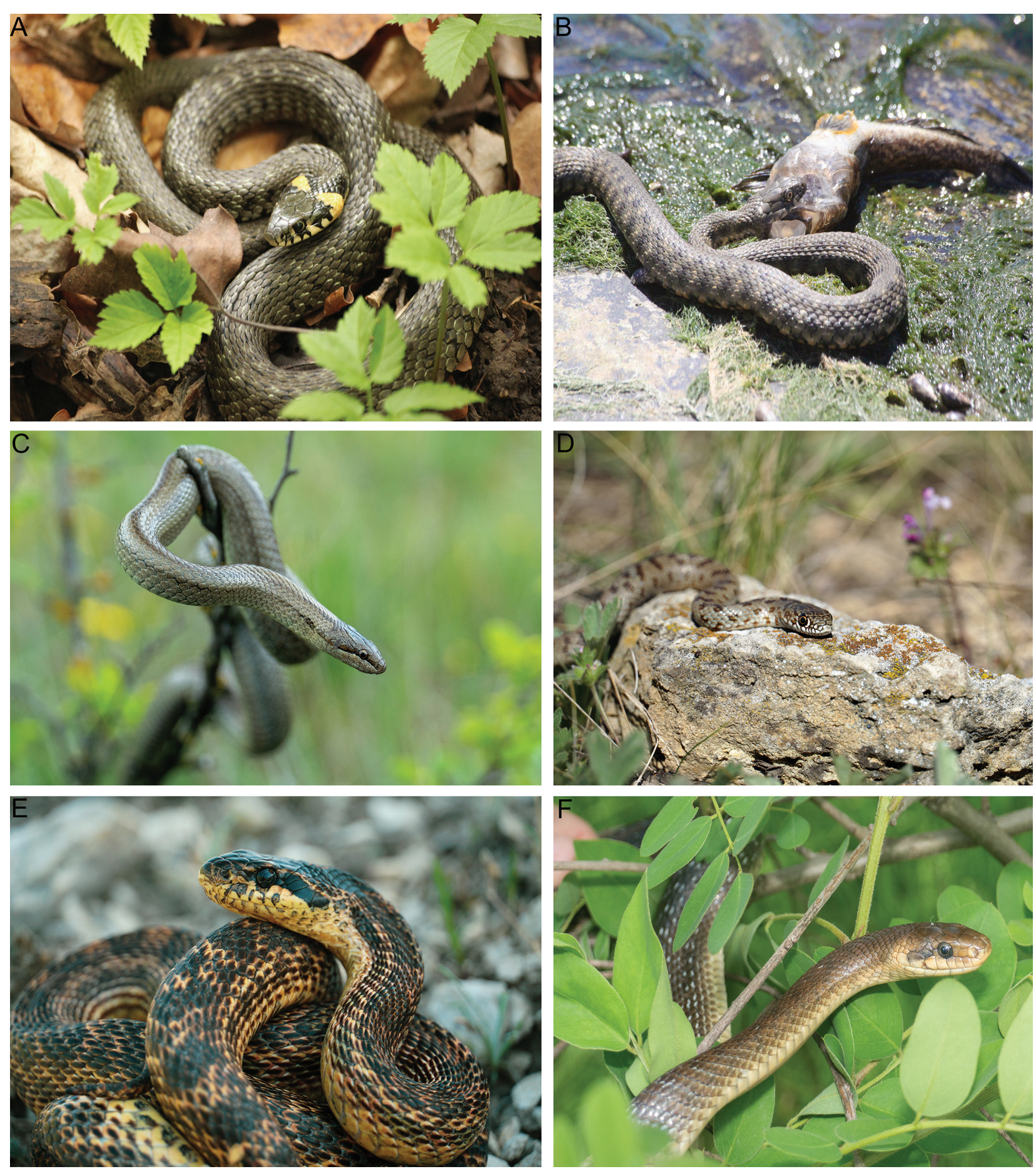

Figure 9. Representative pictures of species of herpetofauna: A. Natrix natrix, Migia; B. Natrix tessellata, Yuzhnoukrainsk; C. Coronella austriaca, Mykolaiv; D. Dolichophis caspius, juvenile, Mykolaiv; E. Elaphe sauromates, valley of the Inhul River; F. Zamenis longissimus, Migia. Photographs by S. Lehkyy (A, B), V. Strenada (C, D, E, F).

of the herpetofauna of Ukraine has not been carried out. Zoogeographically, Ukraine belongs to the Euro-Siberian zone of the western Palearctic (Sindaco et al. 2013). Considering Ukraine's location, its herpetofauna contains both European and Asian elements (Charlemagne 1937; Szczerbak 1982, 1988). Also, the high number of different identified reptile's chorotypes, along with data on the phylogeography of particular species, indicates that the
Northern Black Sea region was colonised from the neighbouring regions, with which it was closely geographically connected during different epochs of the Late Pleistocene and Holocene, i.e. from Balkans, the Ciscaucasia and the Crimea (e.g. Fritz et al. 2009; Guicking et al. 2009; Musilova et al. 2010; Poyarkov et al. 2014; Zinenko et al. 2015; Marzahn et al. 2016; Psonis et al. 2018; Jablonski et al. 2019a, b). However, the North Black Sea region 

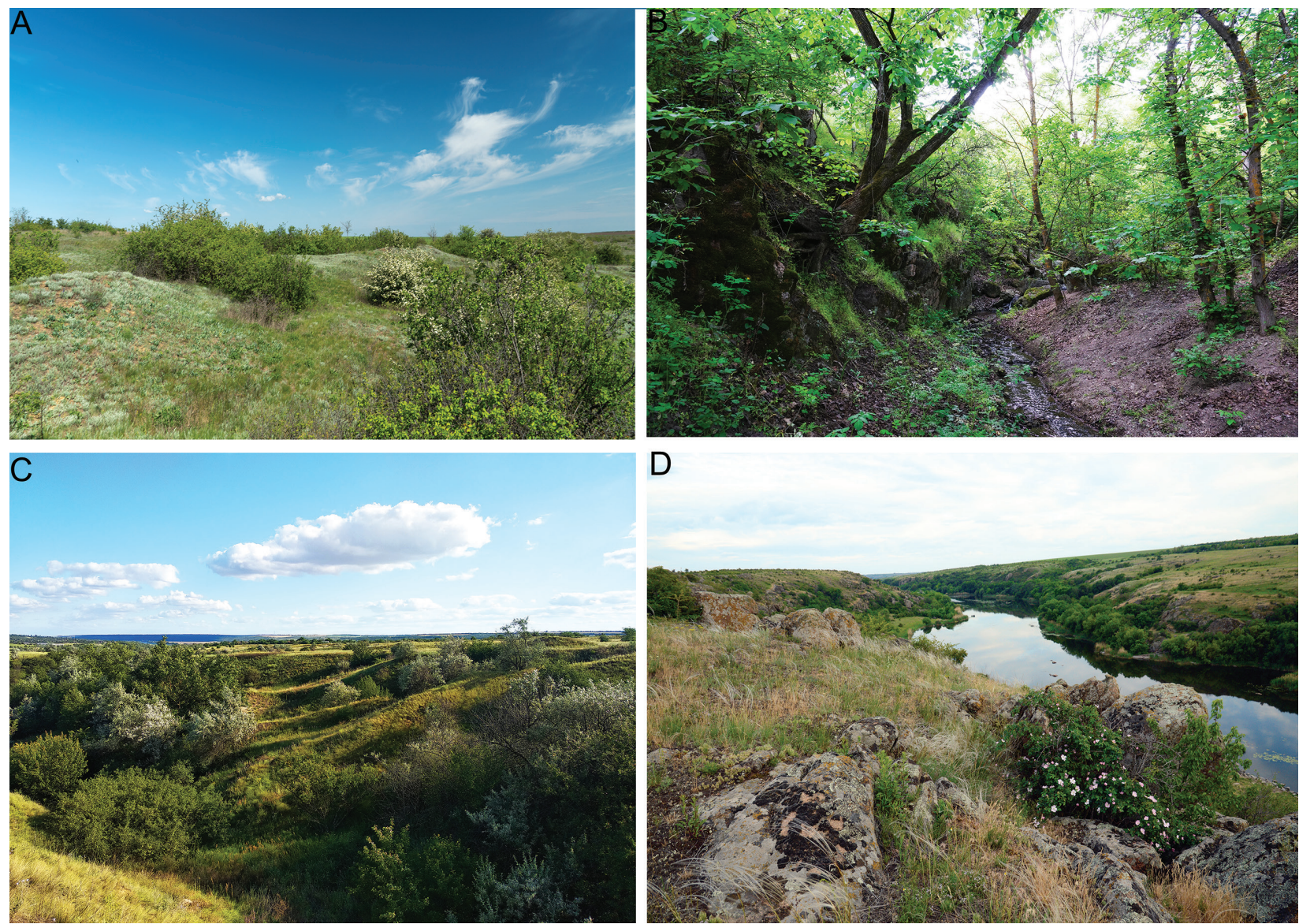

D

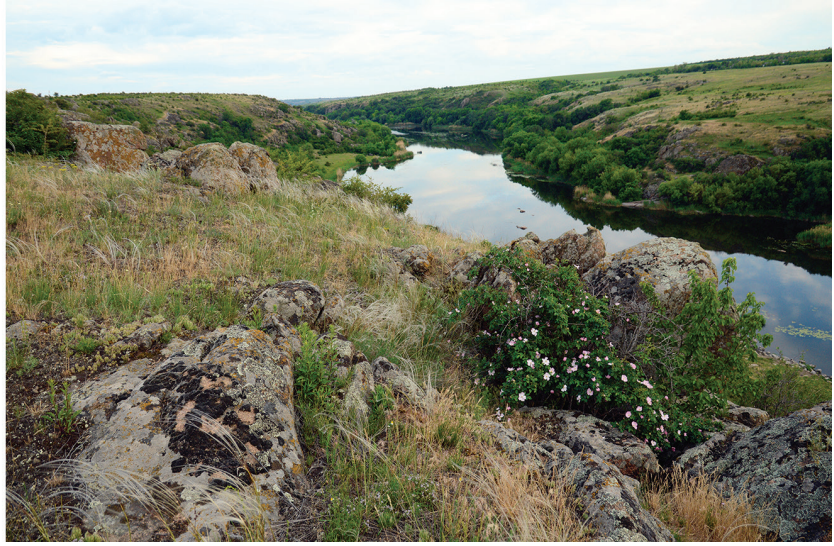

Figure 10. Representative habitats for the herpetofauna in the Mykolaiv Oblast: A. habitat of Coronella austriaca near the village of Zaichevsk; B. habitat of Zamenis longissimus near the village of Grushivka; C. habitat of Podarcis tauricus near the village of Trykhaty; D. Buzk's Gard National Nature Park. Photographs by V. Strenada (A), O. Oskyrko (B, C, D).

may also be a potential source of local genetic diversity for at least some reptile species (see Kukushkin et al. 2020; Mahtani-Williams et al. 2020).

\section{Conservation implications}

The main threats to reptiles in Europe, according to the IUCN Red List, are agriculture, residential/commercial development, and biological resource use. These threats primarily cause habitat fragmentation and loss (Visconti et al. 2018). The steppe biome, which has undergone an extremely strong anthropogenic transformation in south-western Ukraine, is in a particularly endangered position (see Wesche et al. 2016). Specific threats include a plan by South-Ukraine electric power producing complex (SUEPPC) to raise the level of the Oleksandrivske Reservoir by 20,7 metres to provide a major part of the useful capacity of the water storage for logistics water supply to Mykolaiv Oblast (https://www.sunpp.mk.ua/ sites/default/files/documents/zayava_pro_namiri.pdf). This would impact the canyon of the Southern Bug River in between the town of Oleksandrivka, Voznesensk region and the south outskirts of Yuzhnoukrainsk city (including the territory of the Buzk's Gard National Na- ture Park). This move would flood extensive surfaces of rocky habitats and, therefore, will lead to the destruction of natural biotopes and local animal populations including reptiles. In Mykolaiv Oblast, the increasing level of the Oleksandrivske Reservoir can lead to a significant reduction of the suitable habitats for reptiles and increase the risk of species' local extinction. This will destroy habitats of $L$. viridis, D. caspius, and Z. longissimus, included in the Red Book of Ukraine (Akimov 2009). Additionally, the local population of $Z$. longissimus is the only one known in the steppe zone of Ukraine (the nearest known present-day sites are located in Transcarpathia and in the vicinity of the Dniester canyon; Bezman-Moseyko 2010; Dotsenko et al. 2013). In 2019, SUEPPC conducted an environmental impact assessment (EIA) for raising the level of the Oleksandrivske reservoir (http://eia.menr.gov.ua/uploads/documents/564/reports/ qeWQHoa707.pdf). However, this document contains a lot of shortcomings and does not consider the specifics of protected species.

In addition, significant threats include illegal capture of species for the pet trade (e.g., L. viridis) and killing of snakes due to insufficient environmental awareness (Artamonov, 2020 personal observation). These problems are exacerbated by poor enforcement of existing laws, in- 
difference of the local government, people's phobias and taboos regarding reptiles, and lack of environmental education among local people. Threats could be diminished by increased environmental education, actions and control of local government, fines for violating the laws.

The results of this study help with conservation activities for the herpetofauna in southern Ukraine, i) expanding existing protected areas, ii) establishing new protected areas, iii) revising development plans taking into consideration nature conservation needs, iv) establishing legislation against illegal trapping and trade of amphibians and reptiles, v) regular monitoring of populations.

\section{Acknowledgements}

We thank the administration of Buzk's Gard National Nature Park for supporting our research. The authors express their sincere gratitude to Dasha Shyriaieva, Victor Strenada, Roman Lysenko, Daryna Obikhod, Liza Kuznietsova, Tit Volynskiy, Danylo Boromenskyi, Denys Vynokurov and Julia Shcherbakova for their help in field work and Dmytro Omelchenko for help during the analysis. We thank Oleksandr Zinenko for the comments on the distribution of $V$. renardi in this oblast and the reviewers Alexander Strugariu and Oleg Kukushkin for comments that improved the manuscript. This contribution was supported by the Rufford Small Grant "Assessment of conservation status of habitats important for reptiles within the Southern Bug eco-corridor in the steppe zone of Ukraine" (ID 28002-1). DJ was supported by the Slovak Research and Development Agency under the contract no. APVV-19-0076.

\section{References}

Akimov IA (2009) Red Data Book of Ukraine. Animals. Global Consulting, Kyiv, 623 pp. [in Ukrainian]

Arnold N, Ovenden DW (2002) Reptiles and Amphibians of Europe. Collins, London, $288 \mathrm{pp}$

Bannikov AG, Darevsky LS, Rustamov AK (1971) Amphibians and Reptiles of the USSR. Mysl, Moskva, 303 pp. [in Russian]

Baybuz AL, Kukushkin OV, Zinenko OI (2011) On the issue of taxonomical status of steppe viper (Vipera renardi) in Right-bank Ukraine. Visnyk of Dnipropetrovsk University. Biology. Ecology. 19(2): 3-12. https://doi.org/10.15421/011119 [in Russian, English summary]

Bezman-Moseyko OS (2010) New Records of Three Rare Snake Species from the Left Bank of Dniester River (Pridnestrovie). Russian Journal of Herpetology 17(4): 280-284.

Bilyakov IV, Tarashchyuk SV (2008) Distribution of some species of snakes in the north-western Black Sea coast, which are protected in Ukraine. In: Kostyushin VA, Fesenko GV (Eds) Finds of Animals of the Red Book of Ukraine. Ese, Kyiv, 16-21. [in Ukrainian]

Böhme W (1993) Äskulapnatter (Elaphe longissima Laurenti, 1768). In: Böhme W (Ed.) Handbuch der Reptilien und Amphibien Europas. Wiesbaden, Aula Verlag, 331-372. [in German]
Böhme MU, Fritz U, Kotenko T, Džukić G., Ljubisavljević K, Tzankov N, Berendonk TU (2007) Phylogeography and cryptic variation within the Lacerta viridis complex (Lacertidae, Reptilia). Zoologica Scripta 36: 119-131. https://doi.org/10.1111/j.14636409.2006.00262.x

Böhme W, Lymberakis P, Ajtic R, Tok V, Ugurtas IH, Sevinç M, Crochet PA, Haxhiu I, Krecsák L, Sterijovski B, Lymberakis, JCI, Podloucky DC, Avci A (2009) Podarcis tauricus. The IUCN Red List of Threatened Species 2009: e.T61554A12515695. https://doi.org/10.2305/ IUCN.UK.2009.RLTS.T61554A12515695.en

Böhme M, Collen B, Baillie JEM, Bowles P, Chanson J, Cox N, Hammerson G, Hoffmann M, Livingstone SR, Ram M, Rhodin AGJ, Stuart SN, van Dijk PP, Young BE, Afuang LE et al. (2013) The conservation status of the world's reptiles. Biological Conservation 157: 372-385. https://doi.org/10.1016/j.biocon.2012.07.015

Charlemagne M (1937) Zoogeography of Ukrainian SSR. Ukrainian AkademinNauk, Kiev, 235 pp. [in Ukrainian]

Darevsky IS (2006) Consequences of a failed attempt of introduction of bisexual species of rock lizards Darevskia mixta (Mehely, 1909) (Sauria, Lacertidae) from Georgia to Zhitomir region of Ukraine. Vestnik Zoology 40(4): e370. [in Russian]

Darevsky IS, Orlov NL (1988) Rare and endangered animals. Amphibians and Reptiles. Vishaya shkola, Moscow, 463 pp. [in Russian]

Darevsky IS, Szczerbak NN (1968) Acclimatization of parthenogenetic lizards in Ukraine. Priroda 5: e93. [in Russian]

Didukh YaP (2009) Red Book of Ukraine (Flora). Globalconsulting, Kyiv, 911 pp. [in Ukrainian]

Dotsenko IB, Radchenko VI (2005) The Herpetofauna of Antropogenous Landscapes of Nikolayev and Odessa Regions. Proceedings of the Zoological Museum 37: 109-120. [in Russian, English summary]

Dotsenko IB, Vikirchak AK, Drebet MV (2013) New records of Aeskulapian (Forest) snake, Zamenis longissimus (Serpentes, Colubridae), and the recommendations of the species conservation in the territory of Ukraine. Proceedings of the Zoological Museum 44: 123-133. [in Russian, English summary]

Dovzhenko AV (2013) New data on distribution of the Balkan wall lizard Podarcis tauricus (Sauria, Lacertidae) in Khersonskaya and Nikolaevskaya provinces of the Ukraine. The Natural Reserves of the Crimea. Biodiversity and Conservation in Sea of Azov and Black Sea Region. Materials of the $7^{\text {th }}$ International Scientific-Practical Conference (Simferopol, 24-26 October, 2013). Simferopol, Vernadsky Taurida National University: 311-316. [in Russian]

Duz SL, Kukushkin OV, Nazaro RA (2012) Record of the Turkestan naked-toed gecko, Tenuidactylus fedtschenkoi (Sauria: Gekkonidae) in the South-Western Ukraine. Current Studies in Herpetology 12(3/4): 123-133. [in Russian, English summary]

Environmental Impact Assessment (EIA) (2019) Environmental Impact Assessment (EIA): Raising the level of the Oleksandrivske Reservoir to the design mark of $20.7 \mathrm{~m}$. http://eia.menr.gov.ua/uploads/ documents/564/reports/qeWQHoa707.pdf

Fritz U, Ayaz D, Hundsdörfer AK, Kotenko T, Guicking D, Wink M, Tok CV, Çiçek K, Buschbom J (2009) Mitochondrial diversity of European pond turtles (Emys orbicularis) in Anatolia and the Ponto-Caspian Region: Multiple old refuges, hotspot of extant diversification and critically endangered endemics. Organisms, Diversity and Evolution 9: 100-114. https://doi.org/10.1016/j.ode.2009.02.002 
IUCN (2020) The IUCN Red List of Threatened Species. Version 2020 2 https://www.iucnredlist.org

Guicking D, Joger U, Winka M (2009) Cryptic diversity in a Eurasian water snake (Natrix tessellata, Serpentes: Colubridae): Evidence from mitochondrial sequence data and nuclear ISSR-PCR fingerprinting. Organisms Diversity \& Evolution 9(3): 201-214. https:// doi.org/10.1016/j.ode.2009.03.001

Jablonski D, Kukushkin OV, Avci A, Bunyatova S, Kumlutas Y, Ilgaz C, Polyakova E, Shiryaev K, Tuniyev B, Jandzik D (2019) The biogeography of Elaphe sauromates (Pallas, 1814), with a description of a new rat snake species. PeerJ 7: e6944. https://doi.org/10.7717/ peerj.6944

Jablonski D, Nagy ZT, Avcı A, Olgun K, Kukushkin OV, Safaei-Mahroo B, Jandzik D (2019) Cryptic diversity in the smooth snake (Coronella austriaca). Amphibia-Reptilia 40: 179-192. https://doi. org/10.1163/15685381-20181025

Jetz W, McPherson JM, Guralnick RP (2011) Integrating biodiversity distribution knowledge: toward a global map of life. Trends in Ecology \& Evolution 27: 151-159. https://doi.org/10.1016/j. tree.2011.09.007

Kindler C, Böhme W, Corti C, Gvoždík V, Jablonski D, Jandzik D, Metallinou M, Široký P, Fritz U (2013) Mitochondrial phylogeography, contact zones and taxonomy of grass snakes (Natrix natrix, N. megalocephala). Zoologica Scripta 42: 458-472. https://doi. org/10.1111/zsc.12018

Kostyushin V, Kuzemko A, Onischenko V, Chorna G, Taraschuk S, Derkach O, Mishta O, Vorona E, Matveev M, Voznyi Yu, Kutsokon Yu, Kardash S, Vasylyuk A, Kolomitsev G, Novak V, Tarasenko M, Kozak M (2007) The Southern Bug meridional river corridor: biodiversity and valuable areas. Wetlands International Black Sea Programme. Kyiv. 92 pp. [in Ukrainian, English summary]

Kotenko TI (1986) Eremias arguta deserti (Reptilia: Sauria) in the Ukraine. In: Rocek Z (Ed.) Studies in Herpetology, Prague, 479-482.

Kotenko TI (2000) The European pond terrapin (Emys orbicularis) in the steppe zone of Ukraine. Stapfia 69: 87-106.

Kotenko TI (2006) The role of the Azov - Black Sea Ecological Corridor in the conservation of reptiles. Scientific Bulletin of the Uzhgorod University (Ser. Biol.) 19: 20-54. [in Russian, English summary]

Kotenko TI, Kukushkin OV, Zinenko OI (2008) The smooth snake Coronella austriaca Laur. - species of the Red Book of Ukraine. In: Kostyushin VA, Fesenko GV (Eds) Finds of Animals of the Red Book of Ukraine. Ese, Kyiv, 133-151. [in Ukrainian]

Kotenko TI, Sytnik OI (2009) Green lizard Lacerta viridis (Laurenti, 1768) In: Akimov IA (Ed.) Animals. Global Consulting, Kyiv, 389 pp [in Ukrainian]

Kotenko TI, Kukushkin OV (2010) Annotated lists of amphibians and reptiles in Crimea. Scientific notes of the Cape Martyan Reserve 1: 225-26. [in Russian]

Kotenko TI, Shaitan SV, Starkov VG, Zinenko OI (2011) The northern range limit of the dice snake (Natrix tessellata) in Ukraine and the Don River Basin in Russia. Mertensiella 18: 311-325.

Krasylenko YuA, Kukushkin OV (2017) An update of thin-toed gecko Tenuidactylus bogdanovi (Reptilia, Gekkonidae) population status in Odessa city, Ukraine. Zbirnik prac' Zoologicnogo muzeu 48: 3-12.

Kukushkin OV, Ermakov OA, Ivanov AYu, Doronin IV, Sviridenko EYu, Simonov EP, Gorelov RA, Khramova MA, Blokhin IG (2020) Cytochrome b mitochondrial gene analysis-based phylogeography of a Sand lizard in the Crimea: ancient refugium at the peninsula, late expansion from the North, and first evidence of Lacerta agilis tauridica and L. a. exigua (Lacertidae: Sauria) hybridization. Proceedings of the Zoological Institute RAS 324(1): 56-99. https://doi.org/10.31610/trudyzin/2020.324.1.56 [in Russian, English summary]

Kurtyak FF, Kurtyak MF (2013) Slider Turtle, Trachemys scripta elegans (Wied 1839) (Reptilia; Testudines), as invasion threat in Transcarpathia (Ukraine). Scientific Bulletin of the Uzhgorod University (Ser. Biol.) 34: 58-62. [in Ukrainian, English summary]

Kurylenko VG, Verves YuA (1999) Amphibians and Reptiles of Ukraine. Genesa, Kiev, 208 pp. [in Russian]

Kuzemko A, Shyriaieva D, Kolomiiets G (2020) Unique rocky grasslands under threat due to the hydropower and nuclear power plant development in the National Nature Park Buzkyi Gard (South Ukraine). Palaearctic Grasslands 45: 97-98.

Lovich RE, Hayes WK, Mushinsky H, Rodda GH (2012) Transect surveys, including line distance. In: McDiarmid RW, Foster MS, Guyerm C (Eds) Reptile biodiversity, Standard Methods for Inventory and Monitoring. University of California Press, 227-234.

Mahtani-Williams S, Fulton W, Desvars-Larrive A, Lado S, Elbers JP, Halpern B, Herczeg D, Babocsay G, Lauš B, Nagy ZT, Jablonski D, Kukushkin O, Orozco-terWengel P, Vörös J, Burger PA (2020) Landscape Genomics of a Widely Distributed Snake, Dolichophis caspius (Gmelin, 1789) across Eastern Europe and Western Asia. Genes 11(10): e1218. https://doi.org/10.3390/genes11101218

Marushchak O, Nekrasova O, Oskyrko O (2018) Cases of detection of fauna listed in the Red Book of Ukraine in the period from 2010 to 2017. In: Akimov IA, Kharchenko VO, Kostyushin VA, Vasilyuk OV (Eds) Materials for the $4^{\text {th }}$ edition of the Red Book of Ukraine. Fauna 2(7). Druk Art, Chernivtsi, 19-24. [in Ukrainian]

Marzahn E, Mayer W, Joger U, Ilgaz Ç, Jablonski D, Kindler C, Kumlutaş U, Nistri A, Schneeweiss N, Vamberger M, Žagar A, Fritz U (2016) Phylogeography of the Lacerta viridis complex: mitochondrial and nuclear markers provide taxonomic insights. Journal of Zoological Systematics and Evolutionary Research 54(2): 85-105. https://doi.org/10.1111/jzs.12115

Matvyeyev AS, Kukushkin OV, Sokolov LV (2013) Common Wall Lizard, Podarcis muralis (Sauria: Lacertidae), as a new species in the fauna of Ukraine. Proceeding of the Ukrainian Herpetological Society 4: 95-108. [in Russian, English summary]

McDiarmid RW, Foster MS, Guyer C, Gibbons JW, Chernoff N (2012) Reptile Biodiversity: Standard Methods for Inventory and Monitoring. University of California Press, 412 pp. https://doi. org/10.1525/9780520952072

Mizsei E, Zinenko O, Sillero N, Ferri V, Roussos SA, Szabolcs M (2018) The distribution of meadow and steppe vipers (Vipera grae$c a, V$. renardi and $V$. ursinii): a revision of the New Atlas of Amphibians and Reptiles of Europe. Basic and Applied Herpetology 32: 77-83. https://doi.org/10.11160/bah.94

Musilová R, Zavadil V, Marková S, Kotlík P (2010) Relics of the Europe's warm past: Phylogeography of the Aesculapian snake. Molecular Phylogenetics and Evolution 57: 1245-1252. https://doi. org/10.1016/j.ympev.2010.09.017

Mykytynets GI, Suriadna NM, Markautsan OE, Ivanov OG (2019) Findings of reptilian of the Red Book of southern Ukraine. In: Akimov IA, Kharchenko VO, Kostyushin VA, Vasilyuk OV (Eds) Materials for the $4^{\text {th }}$ edition of the Red Book of Ukraine. Fauna 3(7). Druk Art, Chernivtsi, 213-215. [in Ukrainian] 
Nekrasova OD (2013) Herpetofauna of Inhul River Park. In: Konishchuk VV (Ed.) Ecology of wetlands and peatlands. DIA, Kyiv, 200-205. [in Ukrainian]

Nekrasova O, Marushchak O, Oskyrko O (2019) Findings of animals of the fauna of Ukraine listed in the Red Book of Ukraine during 2015 and 2018. In: Akimov IA, Kharchenko VO, Kostyushin VA, Vasilyuk OV (Eds) Materials for the $4^{\text {th }}$ edition of the Red Book of Ukraine. Fauna 3(7). Druk Art, Chernivtsi, 234-236. [in Ukrainian] Oksanen J, Blanchet FG, Friendly M, Kindt R, Legendre P, McGlinn D, Minchin PR, O’Hara RB, Simpson GL, Solymos P, Henry H, Stevens M, Szoecs E, Wagner H (2019) Vegan: Community Ecology Package. R package version 2.5-6. https:/CRAN.R-project.org/package=vegan

Polynova GV, Mishustin SS (2020) Changes in the spatial structure of the Eremias arguta deserti population in semi-deserts of the Astrakhan region. Principy ekologii 2: 87-96. https://doi.org/10.15393/ j1.art.2020.10303 [in Russian, English summary]

Poyarkov NA, Orlova VF, Chirikova MA (2014) The mitochondrial phylogeography and intraspecific taxonomy of the Steppe Racerunner, Eremias arguta (Pallas) (Lacertidae: Sauria, Reptilia), reflects biogeographic patterns in Middle Asia. Zootaxa 3895(2): 208-224. https://doi.org/10.11646/zootaxa.3895.2.4

Psonis N, Antoniou A, Karameta E, Leache AD, Kotsakiozi P, Darriba D, Kozlov A, Stamatakis A, Poursanidis D, Kukushkin O, Jablonski D, Crnobrnja-Isailović J, Gherghel I, Lymberakis P, Poulakakis N (2018) Resolving complex phylogeographic patterns in the Balkan Peninsula using closely related wall-lizard species as a model system. Molecular Phylogenetics and Evolution 125: 100-115. https:// doi.org/10.1016/j.ympev.2018.03.021

Redinov KO (2018) Materials for distribution of rare reptiles in the south of the Ochakiv district of the Mykolaiv region. In: Akimov IA, Kharchenko VO, Kostyushin VA, Vasilyuk OV (Eds) Materials for the $4^{\text {th }}$ edition of the Red Book of Ukraine. Fauna 2(7). Druk Art, Chernivtsi, 184-190. [in Ukrainian]

Sillero N, Campos J, Bonardi A, Corti C, Creemers R, Crochet PA, Crnobrnja JI, Denoël, M, Ficetola GF, Gonçalves J, Kuzmin S, Lymberakis P, Pous de P, Rodríguez A, Sindaco R, Speybroeck J, Toxopeus B, Vieites DR, Vences M (2014) Updated distribution and biogeography of amphibians and reptiles of Europe. Amphibia-Reptilia 35: 1-31. https://doi.org/10.1163/15685381-00002935

Sindaco R, Venchi A, Grieco C (2013) The Reptiles of the Western Palearctic. Volume 2: Annotated Checklist and Distributional Atlas of the Snakes of Europe, North Africa, Middle East and Central Asia, with an Update to Volume 1. Edizioni Belvedere, Latina, Italy, 543 pp.

Sinervo B, Méndez-de-la-Cruz F, Miles DB, Heulin B, Bastiaans E, Villagrán-Santa Cruz M, Lara-Resendiz R, Martínez-Méndez N, Calderón-Espinosa ML, Meza-Lázaro RN, Gadsden H, Avila LJ, Morando M, De la Riva IJ, Sepulveda PV, Rocha CFD, Ibargüengoytía N, Puntriano CA, Massot M, Lepetz V, Oksanen TA, Chapple DG, Bauer AM, Branch WR, Clobert J, Sites JW (2010) Erosion of Lizard Diversity by Climate Change and Altered Thermal Niches. Science 328: 894-899. https://doi.org/10.1126/science.1184695

Suriadna NM, Mykytynets GI, Manuilova OM (2018) Cadastre of registrations of some species of amphibians and reptiles of the south of Ukraine listed in the Red Book. In: Akimov IA, Kharchenko VO, Kostyushin VA, Vasilyuk OV (Eds) Materials for the $4^{\text {th }}$ edition of the Red Book of Ukraine. Fauna 2(7). Druk Art, Chernivtsi, 303-309. [in Ukrainian]

Speybroeck J, Beukema W, Dufresnes C, Fritz U, Jablonski D, Lymberakis P, Martínez-Solano I, Razzetti E, Vamberger M, Vences M,
Vörös J, Crochet PA (2020) Species list of the European herpetofauna - 2020 update by the Taxonomic Committee of the Societas Europaea Herpetologica. Amphibia-Reptilia 41: 139-189. https:// doi.org/10.1163/15685381-bja10010

Strugren B, Rădulescu M (1961) Metode matematice in zoogeografia regionala. Studii şi cercetări de Biologie (Cluj) 12: 7-24. [in Romanian, Russian and German summary]

Szczerbak NN (1982) Gründzuge einer heretogeographischen Gliederung der Paläarktis. Vertebrata hungarica 21: 227-239 [in German]

Szczerbak NN (1988) Zoogeographic division of the Ukrainian SSR. Vestnik Zoology 3: 22-31. [in Russian]

Szczerbak NN (1993) Eremias arguta. Naukova Dumka, Kiev, 237 pp. [in Russian]

Szczerbak NN, Szczerban' MI (1980) Amphibians and Reptiles of the Ukrainian Carpathians. Naukova dumka, Kiev, 266 pp. [in Russian]

Tarashchuk VI (1959) Amphibians and reptiles. In: Bilanovskyi ID, Voinstvenskyi MA, Kasyanenko VG, Markevich OP, Pidoplichko IG (Eds) Fauna of Ukraine (Vol. 7). Academy of Sciences of Ukrainian SSR, Kyiv, 246 pp. [in Ukrainian]

Tarashchuk VI (2007) Conservation of Biodiversity in the Primorsky-steppe eco-corridor. Catalog of Species of Flora and Fauna that are Under Special Protection in Ukraine and are Vulnerable in the Implementation of Forestry Measures. Veselyy dolphin, Kyiv, 112 pp. [in Ukrainian]

Tkach VP (2012) Forests in Ukraine: current situation and development prospects. Ukrainian Geographical Journal 2: 49-55. [in Ukrainian]

Tsvelyh AN (1981) Location and number of herpetofauna in the construction area of the South-Ukrainian nuclear power plant and forecast of its changes. In: Ananjeva NB, Barkagau ZS, Bolkin LJ, Sokolova TM, Szczerbak NN (Eds) Fifth herpetologlcal conference the problems of herpetology society (Ashgabat), September 22-24, 1981. Nauka, Saint Petersburg, 145 pp. [in Russian]

Vigna Taglianti A, Audisio P, Biondi M, Bologna M, Carpaneto G, De Biase A, Fattorini S, Piattella E, Sindaco R, Venchi A, Zapparoli M. (1999) A proposal for a chorotype classification of the Near East fauna, in the framework of the Western Palearctic region. Biogeographia 20: 31-59. https://doi.org/10.21426/B6110172

Visconti P, Elias VV, Sousa PI, Fischer M et al. (2018) Status, trends and future dynamics of biodiversity and ecosystems underpinning Nature's contributions to people. In: Rounsevell M, Fischer M, TorreMarin Rando A, Mader A (Eds) The IPBES Regional Assessment Report on Biodiversity and Ecosystem Services for Europe and Central Asia. IPBES, Secretariat of the Intergovernmental Science-Policy Platform on Biodiversity and Ecosystem Services, Bonn, 187-384.

Voblenko AS, Sheshurak PN, Kedrov BY, Marisova IV (2019) Vertebrates included in the Red Book of Ukraine, identified during the routing field practices on the zoology of Vertebrates of the Nikolay Gogol State University. In: Akimov IA, Kharchenko VO, Kostyushin VA, Vasilyuk OV (Eds) Materials for the $4^{\text {th }}$ edition of the Red Book of Ukraine. Fauna 3(7). Druk Art, Chernivtsi, 52-56. [in Russian]

Wake DB, Vredenburg VT (2008) Are we in the midst of the sixth mass extinction? A view from the world of amphibians. Proceedings of the National Academy of Sciences USA 105 (Suppl. 1): 11466-11473. https://doi.org/10.1073/pnas.0801921105

Wesche K, Ambarlı D, Kamp J, Török P, Treiber J, Dengler J (2016) The Palearctic steppe biome: a new synthesis. Biodiversity Conservation 25: 2197-2231. https://doi.org/10.1007/s10531-016-1214-7 
Yablokov AV (1976) A Sand Lizard. Monographic Description of the Species. Nauka, Moscow, 376 pp.

Zinenko A, Stümpel N, Mazanaeva L, Bakiev A, Shiryaev K, Pavlov A, Kotenko T, Kukushkin O, Chikin Yu, Duisebajeva N, Nilson G, Orlov N, Tuniyev S, Ananjeva NB, Murphy RW, Joger U (2015) Mitochondrial phylogeny shows multiply independent ecological transitions and northern dispersion despite of Pleistocene glaciations in meadow and steppe vipers (Vipera ursinii and Vipera renardi). Molecular Phylogenetics and Evolution 84: 8 -100. https://doi. org/10.1016/j.ympev.2014.12.005

Zizka A, Rydén O, Edler D, Klein J, Aronsson H, Perrigo A, Silvestro D, Jagers SC, Lindberg SI, Antonelli A (2020) Exploring the Impact of Political Regimes on Biodiversity. University of Gothenburg, Varieties of Democracy Institute: Working Paper 98: 1-11. https://doi. org/10.2139/ssrn.3561430

\section{Supplementary material 1}

\section{Records of herpetofaunal species with names of localities and $10 \mathrm{~km}$ UTM codes (UTM Zone $36 \mathrm{~N}$ ) within the Mykolaiv Oblast, Ukraine}

Authors: Oleksandra Oskyrko, Daniel Jablonski

Data type: Adobe PDF file

Copyright notice: This dataset is made available under the Open Database License (http://opendatacommons.org/licenses/ odbl/1.0/). The Open Database License (ODbL) is a license agreement intended to allow users to freely share, modify, and use this Dataset while maintaining this same freedom for others, provided that the original source and author(s) are credited. Link: https://doi.org/10.3897/herpetozoa.34.e62459.supp11 